(2) Open Access Full Text Article

REVIEW

\title{
Impact of everolimus: update on immunosuppressive therapy strategies and patient outcomes after renal transplantation
}

This article was published in the following Dove Press journal:

Transplant Research and Risk Management

2I January 20II

Number of times this article has been viewed

\section{Helio Tedesco-Silva Jr \\ Claudia Rosso Felipe \\ Tainá Veras de Sandes \\ Freitas \\ Marina Pontello Cristeli \\ Carolina Araújo Rodrigues \\ José Osmar Medina Pestana}

Nephrology Division, Hospital do Rim e Hipertensão, Universidade Federal de São Paulo, Brazil
Correspondence: Helio Tedesco-Silva Jr Nephrology Division, Hospital do Rim e Hipertensão, Universidade Federal de São Paulo, Rua Borges Lagoa, 960 II Andar, CEP 04038-002, São Paulo, Brazil

Tel +55 II 50878 II3

Fax +55 II5 0878145

Email heliotedesco@him.com.br
Abstract: Everolimus is an immunosuppressive agent used for the prophylaxis of acute rejection after kidney transplantation. Everolimus inhibits the activity of the serine/threonine kinase mammalian target of rapamycin (mTOR), a key enzyme that controls cell growth and metabolism, producing cell cycle arrest from the G1 to S phase. As a consequence, everolimus has antiproliferative and antineoplastic effects. Everolimus is a drug with a narrow therapeutic index. The pharmacokinetics of everolimus indicates a need for twice-daily dosing. Intra- and interindividual variability and drug-drug interactions suggest the need for therapeutic drug monitoring to maximize the efficacy/toxicity ratio. The good correlation between exposure (area under the concentration-time curve) and trough concentration indicates that monitoring of everolimus trough concentrations is an adequate strategy after kidney transplantation. Everolimus is indicated for low- to moderate-risk de novo kidney transplant candidates. There are no conclusive studies thus far indicating that everolimus can be used in high-risk patients, such as sensitized patients, retransplants, and African Americans. In de novo kidney transplant recipients, the recommended initial dose of everolimus is $0.75 \mathrm{mg}$ twice daily, adjusted to maintain blood trough concentrations of $3-8 \mathrm{ng} / \mathrm{mL}$, in combination with progressive reduction in blood trough cyclosporine concentrations to $25-50 \mathrm{ng} / \mathrm{mL}$. In combination with reduced trough blood tacrolimus concentrations of $4-7 \mathrm{ng} / \mathrm{mL}$ the recommended initial dose of everolimus is $1.5 \mathrm{mg}$ twice daily, adjusted to maintain trough blood concentrations of $3-8 \mathrm{ng} / \mathrm{mL}$. Everolimus can also be used as a conversion strategy, mainly to preserve renal function and to manage patients with malignancy. There is no definition of the ideal strategy for conversion, ie, abrupt or sequential, initial dose of everolimus, or target therapeutic trough blood concentrations. Intensive monitoring is recommended after conversion, especially for acute rejection and proteinuria. Because mTOR is ubiquitous and central to many intracellular processes, an array of adverse reactions may occur, including delayed tissue regeneration, proteinuria, dyslipidemia, diabetes, myelosuppression, infertility, ovarian cysts, and mouth ulcers. Because long-term benefits are the goal of any immunosuppressive strategy, further investigations aiming to understand, prevent, and manage everolimus-related adverse reactions are necessary to mitigate the risks and improve tolerability, allowing maximization of all the benefits of this drug.

Keywords: everolimus, immunosuppression, mTOR inhibitors, calcineurin inhibitors, kidney transplantation

\section{Introduction}

Current immunosuppressive drug regimens are effective for the prevention of early acute rejection episodes after kidney transplantation. Despite a decrease in the rate of acute rejection, there has been no significant improvement in overall graft survival. ${ }^{1}$ Several factors may account for this observation. There are donor-related factors, with 
an increasing use of organs showing a variable degree of structural damage retrieved from expanded criteria deceased donors. ${ }^{2}$ There are recipient-related factors because we are transplanting older patients with more comorbidities. ${ }^{3}$ There are also factors related to the safety, tolerability, and compliance with immunosuppressive regimens. ${ }^{4}$

The safety and tolerability of immunosuppressive regimens is relatively poor, and a substantial number of changes in drug combinations occur during the first years after kidney transplantation. ${ }^{5}$ These changes, regardless of the reason, may increase the risk of late allograft failure. Kidney transplant recipients are still developing infections, mainly during the first year after transplantation, which are associated with inferior patient and graft survival. After the first year of transplantation, death due to cardiovascular events is the leading cause of graft loss. Long-term immunosuppression is also associated with an increased risk of malignancies, death, and graft loss. ${ }^{6}$ Calcineurin inhibitors and corticosteroid-sparing regimens have been explored because the side effects of these drugs are associated with increased risks of cardiovascular death and chronic allograft failure. ${ }^{7}$ Finally, compliance is poor, involving education, social, and financial aspects, and quality of life evaluation. ${ }^{8}$

The strategy of using systemic administration of pharmacological doses of drugs to intervene in the immune system in an attempt to prevent rejection of transplanted organs is intrinsically associated with an array of different and unpredictable adverse reactions. Efficacy, safety, and tolerability are influenced by genetically determined differences in immune response ${ }^{9}$ and in drug transport, metabolism, and sensitivity. ${ }^{10,11}$ Immunosuppressive regimens are selected based on pretransplant risk evaluation that is usually based on population analysis, including variables independently associated with long-term outcomes. Patients at the same risk level usually receive the same drug combination dosed to obtain predefined putative therapeutic concentrations. The efficacy, safety, and tolerability of the selected regimen is unpredictable for an individual patient, and changes may be necessary at various times after transplantation. Continuing development of new immunosuppressive drugs will not solve this complex situation, but will offer more alternatives to treat individual patients.

Considering these facts, two inhibitors of mammalian target of rapamycin (mTOR), sirolimus (rapamycin) and everolimus, have been developed for the prevention of acute rejection after solid organ transplantation. Sirolimus, combined with cyclosporine, was approved by the US Food and Drug Administration (FDA) in 1997 for the prevention of acute rejection after kidney transplantation. Everolimus, combined with reduced doses of cyclosporine, was approved by the European Agency for the Evaluation of Medical Products in 2004 for the prevention of acute rejection after heart and kidney transplantation and by the US FDA in 2010 for the prevention of acute rejection after heart and kidney transplantation.

The mTOR is a conserved serine/threonine kinase that regulates cell growth and metabolism. mTOR is part of two distinct multiprotein complexes, ie, TOR complex 1 (TORC1), which is sensitive to rapamycin, and TORC2, which is not. Drugs that interfere with mTOR function may be useful in the treatment of cancer, cardiovascular disease, and autoimmune and metabolic disorders. ${ }^{12}$ This review will focus on the pharmacology, pharmacokinetics, efficacy, and safety of everolimus in adult kidney transplant recipients, updating previous publications that should also be consulted. ${ }^{13-20}$ Oral formulation, ${ }^{21}$ pharmacokinetic, ${ }^{22}$ and efficacy studies ${ }^{23-25}$ have also been conducted in the pediatric population but will not be reviewed in this manuscript.

\section{Molecular and chemical characteristics}

Everolimus $\left(\mathrm{C}_{53} \mathrm{H}_{83} \mathrm{NO}_{14}\right.$, molecular weight 958.2) is a semisynthetic macrolide derivative developed by introducing a stable 2-hydroxyethyl group substitution at position 40 on the sirolimus molecular structure. The introduction of this group makes this molecule more polar, with increased solubility in several organic solvents. ${ }^{26}$

\section{Pharmacology}

Everolimus has the ability to inhibit acute and chronic immune-mediated allograft responses and tumorigenesis, and forms an intracellular complex with the cytoplasmic immunophilin FK binding protein 12. This complex binds with high affinity, and reversibly inhibits mTOR complex 1 . This kinase is central to many pathways controlling cell growth, proliferation, metabolism, and angiogenesis. ${ }^{12}$ Therefore, everolimus inhibits growth factor (interleukins 2 and 15)-driven proliferation and differentiation of $\mathrm{T}$ and $\mathrm{B}$ cells, as well as other cell lineages, including fibroblasts, smooth muscle cells, and endothelial cells. ${ }^{26}$ Although everolimus is active against B cell proliferation, its effect on antibody production has not been defined clearly. In one study, the primary humoral response after vaccination with $\mathrm{T}$ cell-dependent and $\mathrm{T}$ cell-independent antigens was partially inhibited by treatment with cyclosporine, completely abolished by treatment with mycophenolic acid, but remained intact in those 
patients treated with everolimus. Recall responses were only inhibited by mycophenolic acid. Therefore, everolimus allowed a primary response and boosting of T cell-dependent and T cell-independent secondary humoral responses. ${ }^{27}$

Everolimus has been shown to prevent and reverse acute rejection in preclinical models of kidney, heart, and lung transplantation. ${ }^{13,28}$ In combination therapy, everolimus shows synergistic interactions with cyclosporine in several experimental transplant models in rodents and primates. ${ }^{26,29}$ Everolimus is also effective in combination with fingolimod or mycophenolate mofetil, and does not show an antagonistic effect with tacrolimus in lymphocytes from renal transplant recipients. ${ }^{18}$ Experimental studies have shown that everolimus inhibits the manifestations of chronic rejection that may contribute to graft loss, particularly by inhibiting smooth muscle cell proliferation and preventing neointimal thickening and transplant arteriosclerosis. ${ }^{15}$ These effects were recently confirmed in heart transplant recipients. ${ }^{30}$

In normal cells, mTOR activity is controlled by positive and negative regulators involved in the transmission of signals to mTOR through the phosphatidylinositol 3-kinase and serine/threonine protein kinase Akt and Ras-Raf kinase pathways. Increased mTOR activity appears to be promoted by dysregulation of the regulators of mTOR contributing to tumorigenesis. mTOR signals to initiate ribosomal translation of mRNA into protein leading to increased synthesis of multiple proteins, including several that have been implicated in the pathogenesis of multiple tumor types. This defined role has established mTOR as a major link in tumorigenesis. Preclinical data have supported the pivotal role of mTOR in cancer and led to the development of mTOR inhibitors as a therapeutic target. ${ }^{31}$

\section{Pharmacokinetics}

\section{Absorption, distribution, metabolism, and elimination}

The pharmacokinetics of everolimus have been reviewed in detail previously. ${ }^{32,33}$ In kidney transplant recipients, it is estimated (based on preclinical studies) that $16 \%$ of the oral dose of everolimus is rapidly absorbed, ${ }^{32}$ reaching maximum blood concentration $\left(\mathrm{C}_{\max }\right)$ after 1-2 hours $\left(\mathrm{T}_{\max }\right)$. Everolimus is widely distributed in several tissues ${ }^{34}$ with a mean apparent volume of distribution of $1101(1.55 \mathrm{~L} / \mathrm{kg})$. In the blood, $76 \%-83 \%$ of everolimus is distributed into erythrocytes, and $74 \%$ of the remaining fraction is bound to plasma proteins. Everolimus is converted into 11 metabolites, mainly in the intestine and liver, by the action of cytochrome P450 (CYP) 3A4, 3A5, and 2C8 enzymes. The main metabolites found in blood are hydroxy-everolimus, dihydroxy-everolimus, dimethyl-everolimus, and the ring-opened form of everolimus. Everolimus is the main circulating compound in trough blood samples, with total metabolite concentrations corresponding to $50 \%$ and $100 \%$ of the everolimus concentrations. The clinical importance of everolimus metabolites in the blood of patients, including pharmacodynamics, remains to be evaluated..$^{35}$

Approximately $98 \%$ of everolimus metabolites are excreted in the bile and only $2 \%$ is eliminated in urine. Based on population pharmacokinetics, the apparent clearance is 8.8 L/hour, and the mean elimination half-live ranges from 24-35 hours. ${ }^{32}$ Steady-state blood concentrations are reached usually by day 4 after multiple dosing, with systemic accumulation ranging from 1.6- to 3.0 -fold. ${ }^{36}$ Within the dose range used in kidney transplant recipients, everolimus blood concentrations are proportional to the dose administered. There is also a correlation between $\mathrm{C}_{\min }$ blood concentrations of everolimus and total exposure as measured by area under the curve (AUC). Therefore, $\mathrm{C}_{\text {min }}$ blood concentrations can be used as a surrogate marker for total everolimus exposure. ${ }^{37,38}$

\section{Factors interfering with pharmacokinetics}

In kidney transplant recipients, moderate intra- and interindividual variability in everolimus $\mathrm{C}_{\min }(45 \%, 55 \%$, respectively), $\mathrm{C}_{\max }(24 \%, 33 \%)$, and $\mathrm{AUC}(27 \%, 31 \%)$ were observed during the first six months after transplantation. ${ }^{38}$ Several factors account for this observed variability. In adults, the pharmacokinetic characteristics of everolimus do not differ according to age, weight, or gender. ${ }^{39}$ Black patients may need a higher dose $(20 \%)$ to achieve exposure that is similar to that of non-Black patients. ${ }^{38}$ Patients with moderate hepatic impairment may show a two-fold increase in everolimus concentrations (AUC) and a two-fold prolongation in elimination half-life, without changes in the rate and extent of absorption. Therefore, the dosage of everolimus should be reduced by half in these patients. ${ }^{40}$ There is no correlation between creatinine clearance and the apparent clearance of everolimus, indicating no need for dose adjustments in patients with impaired renal function. ${ }^{41}$

A high-fat meal delayed $\mathrm{T}_{\max }$ by a median of 1.75 hours and reduced $\mathrm{C}_{\max }$ by $53 \%$ and $\mathrm{AUC}$ by $21 \%$. Although $\mathrm{C}_{\min }$ blood everolimus concentrations were not affected, it is recommended that everolimus should be administered consistently either with or without food to minimize longitudinal variability in exposure. ${ }^{42}$ 
The interindividual pharmacokinetic variability of everolimus can be explained by genetically determined different activities of the drug efflux pump, P-glycoprotein, and CYP3A4, 3A5, and 2C8. ${ }^{32}$ The critical role of the CYP3A4 system in everolimus biotransformation increases the risk of drug-drug interactions with other drugs metabolized by this cytochrome system. Coadministration of strong CYP3A inhibitors (ketoconazole, itraconazole, voriconazole, ritonavir) may lead to a 15 -fold increase in everolimus AUC, while coadministration of strong CYP3A inducers (rifampin, rifabutin) may decrease the everolimus AUC by $60 \%$. The concomitant use of these drugs should be avoided or used cautiously. The use of moderate CYP3A inhibitors (up to four-fold increase in everolimus AUC by erythromycin, fluconazole, calcium channel blockers) and inducers (carbamazepine, phenobarbital, phenytoin) also necessitates monitoring of blood everolimus concentrations. ${ }^{36,43}$

\section{Interaction with immunosuppressive drugs Everolimus and cyclosporine}

In healthy subjects, simultaneous administration of cyclosporine microemulsion and everolimus increased the everolimus $\mathrm{C}_{\max }$ and AUC by an average of $82 \%$ and $168 \%$, respectively, but a nine-fold variability was observed across subjects. Everolimus elimination half-lives were unchanged in the presence of cyclosporine. If cyclosporine is not used or removed from an everolimus-cyclosporine immunosuppressive regimen, a two- to three-fold decrease in everolimus exposure is expected. On the other hand, the AUC of cyclosporine was not affected by coadministration of everolimus, although $\mathrm{C}_{\max }$ was significantly higher. ${ }^{44,45}$

\section{Everolimus and tacrolimus}

In an open-label exploratory trial in eight maintenance renal transplant patients, the addition of everolimus $1.5 \mathrm{mg}$ twice daily did not change tacrolimus exposure $\left(\mathrm{C}_{\text {min }}\right.$ $7.9 \pm 3.9$ versus $8.4 \pm 4.0 \mathrm{ng} / \mathrm{mL}$; AUC $132 \pm 56$ versus $134 \pm 70 \mathrm{ng} \cdot \mathrm{h} / \mathrm{mL})$. Tacrolimus dose reduction did not change everolimus exposure $\left(\mathrm{C}_{\min } 3.3 \pm 1.2\right.$ versus $3.0 \pm 1.1 \mathrm{ng} / \mathrm{mL}$; $\mathrm{C}_{\max } 10.4 \pm 5.1$ versus $8.2 \pm 1.3 \mathrm{ng} / \mathrm{mL}$; AUC $58 \pm 20$ versus $49 \pm 10 \mathrm{ng} \cdot \mathrm{h} / \mathrm{mL}$ ). When compared with patients receiving cyclosporine, everolimus exposure was 2.5 -fold higher with cyclosporine relative to tacrolimus. Tacrolimus appears to have a minimal effect on blood everolimus concentrations compared with the influence of cyclosporine. ${ }^{46}$

In a prospective, randomized, Phase II pharmacokinetic study in adult renal transplant recipients, lower-dose normalized tacrolimus concentrations $\left(\mathrm{C}_{\text {min }}\right.$ and $\left.\mathrm{AUC}\right)$ were observed on days 4,14 , and 42 after transplantation in patients receiving everolimus $1.5 \mathrm{mg}$ compared with $0.75 \mathrm{mg}$ twice daily. The apparent clearance of tacrolimus was $18 \%$ higher in patients receiving $1.5 \mathrm{mg}$ twice daily. It is possible that everolimus induces the transport and metabolism of tacrolimus by the CYP3A4 and CYP3A5 isoenzymes, as hypothesized by Pascual et al. ${ }^{47}$

Therefore, the dose of everolimus when combined with tacrolimus needs to be higher than when combined with cyclosporine in order to reach a given everolimus blood concentration. ${ }^{46}$ Patients may also need a higher tacrolimus dose because everolimus significantly decreases the oral bioavailability of tacrolimus in a dose-dependent manner. ${ }^{47}$

\section{Everolimus and sotrastaurin}

Sotrastaurin is an immunosuppressant under development that blocks $\mathrm{T}$ lymphocyte activation via protein kinase $\mathrm{C}$ inhibition. In healthy volunteers, coadministration of a single $2 \mathrm{mg}$ dose of everolimus decreased the sotrastaurin $\mathrm{C}_{\text {max }}$ by $13 \%$ $(638 \pm 295$ versus $539 \pm 211 \mathrm{ng} / \mathrm{mL})$, but did not affect AUC $(3660 \pm 1853$ versus $3630 \pm 2006 \mathrm{ng} \cdot \mathrm{h} / \mathrm{mL}$ ). A single $100 \mathrm{mg}$ dose of sotrastaurin increased the $\mathrm{C}_{\text {max }}$ of everolimus by $15 \%$ (15 \pm 6 versus $16 \pm 6 \mathrm{ng} / \mathrm{mL})$ and AUC by $20 \%$ (114 \pm 50 versus $137 \pm 56 \mathrm{ng} \cdot \mathrm{h} / \mathrm{mL}) .^{48}$ In kidney transplant recipients, the mean AUC of everolimus three months after transplantation was $35 \%$ higher in patients receiving a reduced exposure of cyclosporine than that observed in patients receiving sotrastaurin $300 \mathrm{mg}$ twice daily. The correlation between the $\mathrm{C}_{\min }$ and AUC of everolimus was similar when everolimus was combined with cyclosporine $\left(r^{2}=0.77\right)$ or sotrastaurin $\left(r^{2}=0.87\right){ }^{49}$

\section{Efficacy}

In a double-blind, parallel-group, multicenter Phase II study in de novo kidney transplant recipients receiving cyclosporine and corticosteroids, the incidence of biopsyproven acute rejection episodes within the first six months post-transplantation was lower in patients randomized to receive everolimus in fixed doses of $1 \mathrm{mg}$ twice daily (14.7\%) or $2 \mathrm{mg}$ twice daily (25.7\%) compared with those receiving $0.5 \mathrm{mg}$ twice daily (32.4\%). The incidence of viral and fungal infections was higher among recipients treated with $2 \mathrm{mg}$ twice daily. ${ }^{50}$ In this study, everolimus exposure $\left(\mathrm{C}_{\max }\right.$ and AUC) showed a median three-fold accumulation, which was dose-proportional and stable over time. For a four-fold range of everolimus doses, there were no differential effects on cyclosporine dosing or pharmacokinetics. ${ }^{36}$ Based on the efficacy, safety, and pharmacokinetic findings of this study, 
intermediate doses of everolimus $(0.75 \mathrm{mg}$ and $1.5 \mathrm{mg}$ twice daily) were selected for Phase III trials.

\section{Everolimus combined with cyclosporine in de novo kidney transplantation}

Over the last 12 years, several immunosuppressive strategies have been investigated combining everolimus with cyclosporine. Initially, fixed doses of everolimus $0.75 \mathrm{mg}$ or $1.5 \mathrm{mg}$ twice daily were compared with mycophenolate mofetil $1 \mathrm{~g}$ twice daily in patients receiving full doses of cyclosporine and steroids but with no induction therapy. In two multicenter, double-blind studies (B201 $1^{51,52}$ and B251 ${ }^{53}$ ), efficacy for the prevention of acute rejection was comparable with a mycophenolate mofetil group (Table 1) but inferior graft function was observed at one year (Table 2). During the trial, reduction in cyclosporine doses and exposure resulted in stabilization of graft function and did not increase the rate of biopsy-proven acute rejection, but at the end of three years of follow-up a significant difference in graft function was still favoring the mycophenolate mofetil group (Table 3). At 36 months, no differences in biopsy-proven chronic allograft nephropathy were observed in both studies (B201, 13.4\% versus 11.1\% versus 10.2\%; B251, 11.4\% versus $14.9 \%$ versus $8.7 \%$ ) comparing patients randomized to receive everolimus $0.75 \mathrm{mg}$ twice daily or $1.5 \mathrm{mg}$ twice daily, or mycophenolate mofetil, respectively. No significant differences in mortality were observed, but a higher rate of graft failure was observed in the B201 study among those patients randomized to receive everolimus $1.5 \mathrm{mg}$ twice daily (Table 3).

Table I Summary of efficacy endpoints 12 months after transplantation

\begin{tabular}{|c|c|c|c|c|c|}
\hline Study ID & Study groups & $\mathbf{n}$ & BPAR (\%) & Graft loss (\%) & Death (\%) \\
\hline \multirow[t]{3}{*}{$\mathrm{B} 20 \mathrm{I}^{52}$} & $\mathrm{CsA}_{\mathrm{f}}+\mathrm{EVR} 0.75 \mathrm{mg}$ bid & 194 & 23.2 & 4.6 & 5.2 \\
\hline & $\mathrm{CsA}_{f}+\mathrm{EVR} \mathrm{I.5} \mathrm{mg}$ bid & 198 & 19.7 & 10.6 & 4.0 \\
\hline & $\mathrm{CsA}_{\mathrm{f}}+\mathrm{MMF}$ I g bid & 196 & 24.0 & 9.2 & 2.6 \\
\hline \multirow[t]{3}{*}{$\left.B 25\right|^{53}$} & $\mathrm{CsA}_{\mathrm{f}}+\mathrm{EVR} 0.75 \mathrm{mg}$ bid & 193 & 19.2 & 8.8 & 3.1 \\
\hline & $\mathrm{CsA}_{\mathrm{f}}+\mathrm{EVR} \mathrm{I} .5 \mathrm{mg}$ bid & 194 & 22.2 & 4.1 & 3.6 \\
\hline & $\mathrm{CsA}_{f}+\mathrm{MMF}$ I g bid & 196 & 24.0 & 5.1 & 2.0 \\
\hline \multirow[t]{2}{*}{$\mathrm{B} 156^{59}$} & $\mathrm{CsA}_{\mathrm{f}}+$ EVR I.5 mg bid (basiliximab) & 53 & 17 & 5.7 & 3.8 \\
\hline & CsA $A_{r}+$ EVR 1.5 mg bid (basiliximab) & 58 & $6.9^{*}$ & 1.7 & 0 \\
\hline \multirow[t]{2}{*}{$A 2306^{63}$} & $\mathrm{CsA}_{\mathrm{r}}+\mathrm{EVR} 0.75 \mathrm{mg}$ bid adjusted to $>3 \mathrm{ng} / \mathrm{mL}$ & 112 & 25.9 & 5.4 & 0.9 \\
\hline & $\mathrm{CsA}_{\mathrm{r}}+\mathrm{EVR} 1.5 \mathrm{mg}$ bid adjusted to $>3 \mathrm{ng} / \mathrm{mL}$ & 125 & 19.2 & 3.2 & 4.8 \\
\hline \multirow[t]{2}{*}{$\mathrm{A} 2307^{63}$} & CsA + EVR $0.75 \mathrm{mg}$ bid adjusted to $>3 \mathrm{ng} / \mathrm{mL}$ (basiliximab) & 117 & 13.7 & 1.7 & 0 \\
\hline & $\mathrm{CsA}_{\mathrm{r}}+\mathrm{EVR} 1.5 \mathrm{mg}$ bid adjusted to $>3 \mathrm{ng} / \mathrm{mL}$ (basiliximab) & 139 & 15.8 & 5.0 & 1.4 \\
\hline \multirow[t]{3}{*}{ B230964 } & $\mathrm{CsA}_{\mathrm{r}}+\mathrm{EVR} 0.75 \mathrm{mg}$ bid adjusted to $3-8 \mathrm{ng} / \mathrm{mL}$ (basiliximab) & 277 & 16.2 & 4.3 & 2.5 \\
\hline & $\mathrm{CsA}_{\mathrm{r}}+\mathrm{EVR} 1.5 \mathrm{mg}$ bid adjusted to $6-12 \mathrm{ng} / \mathrm{mL}$ (basiliximab) & 279 & 13.3 & 4.7 & 3.2 \\
\hline & $\mathrm{CsA}_{\mathrm{f}}+$ MPA $720 \mathrm{mg}$ bid (basiliximab) & 277 & 17 & 3.2 & 2.2 \\
\hline \multirow[t]{2}{*}{ EVLEC $^{65}$} & $\mathrm{CsA}_{\mathrm{r}}+\mathrm{EVR}_{\mathrm{s}}$ (basiliximab) & 143 & 14.7 & 9.9 & 1.4 \\
\hline & $\mathrm{CsA}_{\mathrm{vl}}+\mathrm{EVR}_{\mathrm{h}}$ (basiliximab) & 142 & 11.9 & 2.1 & 1.4 \\
\hline \multirow[t]{2}{*}{ A242066 } & $\mathrm{CsA}_{\mathrm{r}}+\mathrm{EVR} 0.75 \mathrm{mg}$ bid adjusted to $3-8 \mathrm{ng} / \mathrm{mL}$ (basiliximab) & 65 & 20.0 & 9.2 & 7.7 \\
\hline & $\mathrm{CsA}_{\mathrm{f}}+\mathrm{MPA} \rightarrow$ EVR $0.75 \mathrm{mg}$ bid adjusted to $3-8 \mathrm{ng} / \mathrm{mL}$ (basiliximab) & 74 & 20.3 & 6.8 & 2.7 \\
\hline \multirow[t]{2}{*}{ CRADUS0967 } & $\mathrm{TAC}_{\mathrm{r}}+\mathrm{EVR} 1.5 \mathrm{mg}$ bid adjusted to $3-12 \mathrm{ng} / \mathrm{mL}$ (basiliximab) & 49 & 14 & 0 & 0 \\
\hline & $\mathrm{TAC}_{\mathrm{f}}+\mathrm{EVR} 1.5 \mathrm{mg}$ bid adjusted to $3-12 \mathrm{ng} / \mathrm{mL}$ (basiliximab) & 43 & 14 & 2.3 & 0 \\
\hline \multirow[t]{2}{*}{ ASSET 69} & $\mathrm{TAC}_{\mathrm{r}-\mathrm{Vl}}+\mathrm{EVR} \mathrm{I} .5 \mathrm{mg}$ bid adjusted to $3-8 \mathrm{ng} / \mathrm{mL}$ (basiliximab) & 107 & $18.7^{*}$ & 7.5 & 2.8 \\
\hline & $\mathrm{TAC}_{\mathrm{r}}+\mathrm{EVR}$ I.5 mg bid adjusted to $3-8 \mathrm{ng} / \mathrm{mL}$ (basiliximab) & 117 & 7.7 & 1.7 & 2.6 \\
\hline
\end{tabular}

Notes: All patients received steroids. B20I: CsA $\mathrm{CsA} C_{0}$ concentration I50-400 ng/mL (0-I month) and I00-300 ng/mL (2-I2 months); B25I: CsA: CsA C concentration 200-350 ng/mL (0-I month) and 100-300 ng/mL (2-12 months); B I56: CsA $\mathrm{C}_{\mathrm{f}} \mathrm{CsA}_{\mathrm{O}}$ concentration I50-300 ng/mL (0-2 months) and I25-250 ng/mL (3-36 months); $\mathrm{CsA}_{\mathrm{r}}$ : CsA C concentration 75-125 ng/mL (0-2 months) and 50-100 ng/mL (3-36 months); A2306: CsA : CsA C concentration I000-1400 ng/mL (0-I month), 700-900 ng/mL (I-2 months); $550-650 \mathrm{ng} / \mathrm{mL}$ (3-4 months) and 350-450 ng/mL (4-12 months); A2307: CsA : CsA C concentration 500-700 ng/mL (0-2 months)

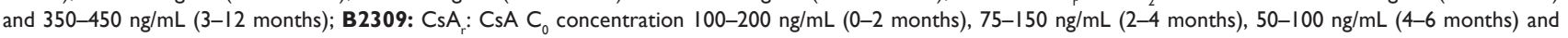
25-50 ng/mL (6-12 months), CsA: CsA C concentration 200-300 ng/mL (0-2 months) and I00-250 ng/mL (2-I2 months); EVLEC: CsA + EVR: CsA C concentration $500-700 \mathrm{ng} / \mathrm{mL}$ (0-2 months), 350-500 ng/mL (2-6 months) and 350-450 ng/mL (6-12 months) + EVR 0.75 bid adjusted to 3-8 ng/mL, CsA $500-700 \mathrm{ng} / \mathrm{mL}$ (0-7 days), 250-450 ng/mL (8 days-2 months), 200-400 ng/mL (3-4 months) and I50-300 ng/mL (6-12 months) + EVR 0.75 bid adjusted to 3-8 ng/mL

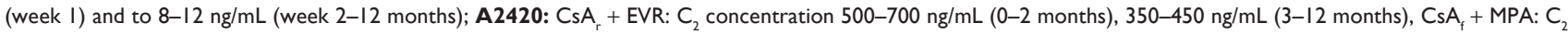
concentration I I $00-1500 \mathrm{ng} / \mathrm{mL}$ (0-I months), $500-700 \mathrm{ng} / \mathrm{mL}$ (I-2 months), $350-450 \mathrm{ng} / \mathrm{mL}$ (3-I2 months) + MPA converted at week 5 to EVR 0.75 bid adjusted to $3-8$ ng/mL; CRADUS09: TAC: TAC $C_{0}$ concentration 4-7 ng/mL (0-3 months) and 3-6 ng/mL (4-6 months), TAC: TAC C concentration 8-I I ng/mL (0-3 months) and 7-10 ng/mL (4-6 months); ASSET: TAC $\mathrm{r}_{\mathrm{v} v \mathrm{v}}:$ TAC $\mathrm{C}_{0}$ concentration 4-7 ng/mL (0-4 months) and I.5-3 ng/mL (4-12 months); TAC : TAC C concentration 4-7 ng/mL (0-12 months). $* P<0.05$ versus control group.

Abbreviations: BPAR, biopsy-proven acute rejection; $\mathrm{Cs}_{\mathrm{f}}$, full cyclosporine exposure; $\mathrm{Cs}_{\mathrm{r}}$, reduced cyclosporine exposure; $\mathrm{Cs}_{\mathrm{vl}}$, very low cyclosporine exposure;

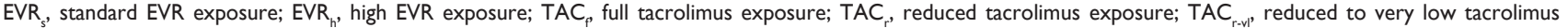
exposure; MPA, mycophenolic acid; bid, twice daily. 
Table 2 Summary of renal function 12 months after transplantation

\begin{tabular}{|c|c|c|}
\hline Study ID & Study groups & $\mathrm{CrCl}(\mathrm{mL} / \mathrm{min})^{\#}$ \\
\hline \multirow[t]{3}{*}{$\mathrm{B} 20 \mathrm{I}^{52}$} & $\mathrm{CsA}_{\mathrm{f}}+\mathrm{EVR} 0.75 \mathrm{mg}$ bid & $52.9 \pm 20.89 *$ \\
\hline & $\mathrm{CsA}_{\mathrm{f}}+\mathrm{EVR} \mathrm{I} .5 \mathrm{mg}$ bid & $49.3 \pm 16.95 *$ \\
\hline & $\mathrm{CsA}_{f}+\mathrm{MMF}$ I g bid & $56.9 \pm 14.75$ \\
\hline \multirow[t]{3}{*}{$B 25 I^{53}$} & $\mathrm{CsA}_{\mathrm{f}}+\mathrm{EVR} 0.75 \mathrm{mg}$ bid & $58(7-124)^{*}$ \\
\hline & $\mathrm{CsA}_{\mathrm{f}}+\mathrm{EVR} 1.5 \mathrm{mg}$ bid & $52(6-196)^{*}$ \\
\hline & $\mathrm{CsA}_{f}+\mathrm{MMF}$ I g bid & $69(8-153)$ \\
\hline \multirow[t]{2}{*}{$\mathrm{B} 156^{59}$} & $\mathrm{CsA}_{\mathrm{f}}+$ EVR I.5 mg bid (basiliximab) & $53.5 \pm 12.1 *$ \\
\hline & CsA $A_{r}+$ EVR I.5 mg bid (basiliximab) & $60.9 \pm 11.3$ \\
\hline \multirow[t]{2}{*}{$A 2306^{63}$} & $\mathrm{CsA}_{\mathrm{r}}+\mathrm{EVR} 0.75 \mathrm{mg}$ bid adjusted to $>3 \mathrm{ng} / \mathrm{mL}$ (basiliximab) & $65 \pm 24.5$ \\
\hline & $\mathrm{CsA}_{\mathrm{r}}+\mathrm{EVR} 1.5 \mathrm{mg}$ bid adjusted to $>3 \mathrm{ng} / \mathrm{mL}$ (basiliximab) & $64 \pm 22.6$ \\
\hline \multirow[t]{2}{*}{$A 2307^{63}$} & $\mathrm{CsA}_{\mathrm{r}}+\mathrm{EVR} 0.75 \mathrm{mg}$ bid adjusted to $>3 \mathrm{ng} / \mathrm{mL}$ (basiliximab) & $67 \pm 24.2$ \\
\hline & 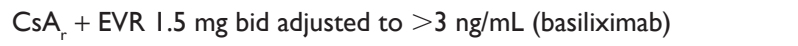 & $64 \pm 19.6$ \\
\hline \multirow[t]{3}{*}{ B230964 } & $\mathrm{CsA}_{\mathrm{r}}+\mathrm{EVR} 0.75 \mathrm{mg}$ bid adjusted to $3-8 \mathrm{ng} / \mathrm{mL}$ (basiliximab) & $68.8 \pm 23.3$ \\
\hline & $\mathrm{CsA}_{\mathrm{r}}+\mathrm{EVR} 1.5 \mathrm{mg}$ bid adjusted to $6-12 \mathrm{ng} / \mathrm{mL}$ (basiliximab) & $67.3 \pm 23.7$ \\
\hline & $\mathrm{CsA}_{\mathrm{f}}+\mathrm{MPA} 720 \mathrm{mg}$ bid (basiliximab) & $67.9 \pm 25.7$ \\
\hline \multirow[t]{2}{*}{ EVLEC $^{65}$} & $\mathrm{CsA}_{r}+\mathrm{EVR}_{s}$ (basiliximab) & $62.5 \pm 20.7$ \\
\hline & $\mathrm{CsA}_{\mathrm{vl}}+\mathrm{EVR}_{\mathrm{h}}$ (basiliximab) & $61.3 \pm 22.0$ \\
\hline \multirow[t]{2}{*}{ A242066 } & $\mathrm{CsA}_{\mathrm{r}}+\mathrm{EVR} 0.75 \mathrm{mg}$ bid adjusted to $3-8 \mathrm{ng} / \mathrm{mL}$ (basiliximab) & $48.4 \pm 21.3$ \\
\hline & $\mathrm{CsA}_{\mathrm{f}}+$ MPA (basiliximab) $\rightarrow$ EVR $0.75 \mathrm{mg}$ bid adjusted to $3-8 \mathrm{ng} / \mathrm{mL}$ & $49.0 \pm 22.2$ \\
\hline \multirow[t]{2}{*}{ CRADUS0967 } & $\mathrm{TAC}_{\mathrm{r}}+\mathrm{EVR} 1.5 \mathrm{mg}$ bid adjusted to $3-12 \mathrm{ng} / \mathrm{mL}$ (basiliximab) & $82.8 \pm 26.8$ \\
\hline & $\mathrm{TAC}_{\mathrm{f}}+\mathrm{EVR} 1.5 \mathrm{mg}$ bid adjusted to $3-12 \mathrm{ng} / \mathrm{mL}$ (basiliximab) & $77.2 \pm 21.8$ \\
\hline \multirow[t]{2}{*}{ ASSET $^{69}$} & $\mathrm{TAC}_{\mathrm{r}-\mathrm{Vl}}+\mathrm{EVR} \mathrm{I} .5 \mathrm{mg}$ bid adjusted to $3-8 \mathrm{ng} / \mathrm{mL}$ (basiliximab) & $67.1 \pm 23.0$ \\
\hline & TAC $_{r}+$ EVR I.5 mg bid adjusted to $3-8 \mathrm{ng} / \mathrm{mL}$ (basiliximab) & $61.1 \pm 19.7$ \\
\hline
\end{tabular}

Notes: "Cockcroft-Gault formula; $P<0.05$ versus control group.

Abbreviations: $\mathrm{CrCl}$, creatinine clearance; $\mathrm{Cs}_{\mathrm{f}}$, full cyclosporine exposure; $\mathrm{Cs}_{\mathrm{r}}$, reduced cyclosporine exposure; $\mathrm{Cs}_{\mathrm{vl}}$, very low cyclosporine exposure; $\mathrm{EVR}_{\mathrm{s}}$, standard EVR exposure; $E_{R}$, high EVR exposure; $T_{A C}$, full tacrolimus exposure; TAC ${ }_{r}$, reduced tacrolimus exposure; TAC ${ }_{r-v l}$, reduced to very low tacrolimus exposure; $M P A$, mycophenolic acid; bid, twice daily.

Everolimus and cyclosporine displayed synergistic immunosuppressive activity when used in combination in vitro and in preclinical models, predicting that they could be used together at lower doses in humans. ${ }^{26,29,54}$ Adequate efficacy, but with a synergistic nephrotoxic effect, was observed in kidney transplant recipients receiving everolimus in combination with full doses of cyclosporin. ${ }^{51-53}$ These initial findings were the first evidence of the complex synergist pharmacokinetic and pharmacodynamic drug-drug interaction between everolimus and cyclosporine in kidney transplant recipients. ${ }^{55,56}$ At that time, basiliximab, an interleukin-2 receptor antagonist monoclonal antibody, had demonstrated efficacy for the prevention of acute rejection in kidney transplant recipients. ${ }^{57,58}$ These findings provided the rationale for using basiliximab induction and everolimus in combination, with reduced doses of cyclosporine to mitigate renal toxicity without loss of immunosuppressive efficacy.

In a subsequent, exploratory, open-label study, fixed doses of everolimus $1.5 \mathrm{mg}$ twice daily were combined with full or reduced ( $50 \%$ reduction) cyclosporine exposure

Table 3 Summary of efficacy endpoints and renal function at 36 months after transplantation

\begin{tabular}{|c|c|c|c|c|c|c|}
\hline Study ID & Study groups & $\mathbf{n}$ & BPAR (\%) & Graft loss (\%) & Death (\%) & $\mathrm{CrCl}(\mathrm{mL} / \mathrm{min})$ \\
\hline \multirow[t]{3}{*}{$\mathrm{B} 20 \mathrm{I}^{52}$} & $\mathrm{CsA}_{\mathrm{f}}+\mathrm{EVR} 0.75 \mathrm{mg}$ bid & 194 & 24.2 & 7.2 & 7.7 & $55 \pm 23$ \\
\hline & $\mathrm{CsA}_{\mathrm{f}}+\mathrm{EVR} 1.5 \mathrm{mg}$ bid & 198 & 24.7 & $16.7^{\#}$ & 9.1 & $50 \pm 2 I^{*}$ \\
\hline & $\mathrm{CsA}_{\mathrm{f}}+\mathrm{MMF}$ I g bid & 196 & 26.5 & 10.7 & 8.2 & $57 \pm 21$ \\
\hline \multirow[t]{3}{*}{$B 251^{53}$} & $\mathrm{CsA}_{\mathrm{f}}+\mathrm{EVR} 0.75 \mathrm{mg}$ bid & 193 & 25.4 & 11.9 & 6.2 & $57(4-140)^{*}$ \\
\hline & $\mathrm{CsA}_{f}+\mathrm{EVR} 1.5 \mathrm{mg}$ bid & 194 & 25.8 & 7.7 & 6.7 & $49(3-113)^{*}$ \\
\hline & $\mathrm{CsA}_{\mathrm{f}}+\mathrm{MMF}$ I g bid & 196 & 26.5 & 7.1 & 6.1 & $70(8-157)$ \\
\hline \multirow[t]{2}{*}{$\mathrm{B} 156^{59}$} & $\mathrm{CsA}_{\mathrm{f}}+\mathrm{EVR}$ I.5 mg bid (basiliximab) & 53 & 18.9 & $13.2^{*}$ & 9.4 & $51.7 \pm 13.1$ \\
\hline & CsA + EVR I.5 mg bid (basiliximab) & 58 & 12.1 & 3.4 & 3.4 & $56.6 \pm 20.0$ \\
\hline
\end{tabular}

Notes: ${ }^{P}<0.05$ versus EVR $0.75 \mathrm{mg}$ bid; $* P<0.05$ versus control group.

Abbreviations: BPAR, biopsy-confirmed acute rejection; $\mathrm{CrCl}$, creatinine clearance; EVR, everolimus; CsA, full cyclosporine exposure; CsA, reduced cyclosporine exposure; MMF, mycophenolate mofetil; bid, twice daily. 
in combination with steroids and basiliximab induction. At one and three years, the incidence of biopsy-proven acute rejection was lower (Table 1), and graft function was superior in the group of patients receiving reduced-dose cyclosporine (Table 2), which supports the hypothesis of a synergistic drug-drug interaction when these two drugs are combined. The differences in renal function at one year were high enough (Table 2) to generate an amendment to the protocol to reduce cyclosporine doses in the control arm, thereby reducing the difference in renal function between the two groups at three years (Table 3 ). ${ }^{59}$

In the B201 and B251 studies, the everolimus dose ( 0.75 or $1.5 \mathrm{mg}$ twice daily) did not correlate with the incidence of biopsy-proven acute rejection. This finding could be explained by a considerable overlap of trough everolimus blood concentrations observed in those patients receiving these two dose levels. ${ }^{14}$ On the other hand, a retrospective analysis of 3355 trough everolimus blood concentrations $\left(\mathrm{C}_{\text {min }}\right)$ from the 695 patients in these two studies showed that freedom from acute rejection was significantly related to the $\mathrm{C}_{\min }$ of everolimus. Freedom from biopsy-proven acute rejection was $68 \%$ at an everolimus $\mathrm{C}_{\min }$ of $1.0-3.4 \mathrm{ng} / \mathrm{mL}$, $81 \%-86 \%$ at $3.5-7.7 \mathrm{ng} / \mathrm{mL}$, and $91 \%$ at $7.8-15.0 \mathrm{ng} / \mathrm{mL}$. This analysis identified an everolimus $\mathrm{C}_{\text {min }}$ of $3 \mathrm{ng} / \mathrm{mL}$ as the lower therapeutic concentration when everolimus is combined with cyclosporine and steroids. ${ }^{60}$

The design of subsequent studies was based on the following information available at that time: use of reduced cyclosporine exposure was associated with improved safety (preserved renal function) and similar efficacy (incidence of biopsy-proven acute rejection); ${ }^{59}$ therapeutic $\mathrm{C}_{\text {min }}$ blood everolimus concentrations should be above $3 \mathrm{ng} / \mathrm{mL} ;{ }^{60}$ and blood cyclosporine concentration two hours after the morning dose (C2) was a superior surrogate of cyclosporine exposure compared with $\mathrm{C}_{\min }$ concentrations. ${ }^{61}$ To explore a wider range of immunosuppressive alternatives, two prospective trials were designed, comprising one study which used progressive reduction in cyclosporine $\mathrm{C} 2$ concentrations without induction therapy ${ }^{62,63}$ and another study which used basiliximab induction with initially reduced cyclosporine C2 concentrations. ${ }^{62,63}$ African American patients were not randomized, and received initial $1.5 \mathrm{mg}$ twice daily doses of everolimus because these patients have a higher immunological risk and higher everolimus clearance compared with Caucasian patients. ${ }^{39}$ In both studies, two everolimus dose levels were used, enabling prospective therapeutic drug monitoring to ensure everolimus concentrations higher than $3 \mathrm{ng} / \mathrm{mL}$.
These two studies produced essentially similar results. At one year, the efficacy of the two initial everolimus dosing regimens $(0.75 \mathrm{mg}$ or $1.5 \mathrm{mg}$ twice daily), ensuring an everolimus $\mathrm{C}_{\min }$ above $3 \mathrm{ng} / \mathrm{mL}$, in combination with progressive reduction in cyclosporine exposure and without induction, was similar to that observed in the B201 and B251 studies (Table 1). A slightly higher incidence of biopsyproven acute rejection in the low-dose everolimus group, which was not observed in the study with induction, may be due to the fact that a higher proportion of patients in the lowdose group showed everolimus concentrations lower than $3 \mathrm{ng} / \mathrm{mL}$ during the first two weeks after transplantation. ${ }^{62,63}$ A lower incidence of biopsy-proven acute rejection was observed in the study using basiliximab induction, conferring further protection, while everolimus doses were adjusted to obtain concentrations above $3 \mathrm{ng} / \mathrm{mL} .^{62,63}$ Patients in both studies showed comparable graft function but the lack of an adequate parallel control in these trials precluded any final conclusions from use of these strategies (Table 2). Furthermore, no clear difference in the efficacy/toxicity analysis was made comparing both everolimus dose levels, perhaps because, again, significant overlap in everolimus concentrations was observed in patients receiving everolimus 0.75 or $1.5 \mathrm{mg}$ twice daily. ${ }^{62,63}$

To consolidate the findings of these previous studies, a large, prospective, multicenter trial was designed based on the following information: as a result of: a need to confirm the additional benefits for the prevention of biopsy-proven acute rejection of basiliximab induction therapy in patients receiving cyclosporine and everolimus; no universal acceptability and clinical utility of using cyclosporine $\mathrm{C} 2$ monitoring over $\mathrm{C}_{\min }$ as a surrogate marker of cyclosporine exposure; a need to evaluate prospectively two concentration levels of everolimus instead of two dose levels; and a need for an adequate parallel control arm. Considering these issues, in the following study: all patients received basiliximab induction; cyclosporine doses were adjusted to obtain a predefined and progressively reduced $\mathrm{C}_{\text {min }}$ identified in the previous study with basiliximab induction (where cyclosporine doses were adjusted based on $\mathrm{C} 2$ concentrations but $\mathrm{C}_{\text {min }}$ was collected simultaneously); everolimus doses were adjusted to obtain a target $\mathrm{C}_{\min }$ of 3-8 $\mathrm{ng} / \mathrm{mL}$ for the lower initial dose group (0.75 $\mathrm{mg}$ twice daily) and 6-12 $\mathrm{ng} / \mathrm{mL}$ for the initial higher dose group (1.5 mg twice daily); and a control arm using full doses of cyclosporine and mycophenolate sodium $720 \mathrm{mg}$ twice daily. ${ }^{64}$ In this study, cyclosporine $\mathrm{C}_{\text {min }}$ was $60 \%$ lower in both everolimus groups compared with cyclosporine and mycophenolate sodium at one year. Noninferior efficacy 
(composite of biopsy-proven acute rejection, graft loss, death, or loss to follow-up) and renal function was observed comparing the higher and lower everolimus target concentrations with the control arm (Table 1). For the first time, a concentration-dependent higher incidence of selected adverse events was observed in the everolimus arms, indicating that progressive reduction in cyclosporine concentrations in combination with everolimus concentrations in the $3-8 \mathrm{ng} / \mathrm{mL}$ range provides the best risk/benefit assessment. ${ }^{64}$

To explore further the interaction between cyclosporine and everolimus, mainly due to the different adverse event profiles related to each drug class (cyclosporine or everolimus), another prospective trial investigated the risk/benefit ratio of using everolimus with very low-exposure cyclosporine. In this study, very low-dose cyclosporine (C2, 150-300 ng/mL) and high-dose everolimus $\left(\mathrm{C}_{\min } 8-12 \mathrm{ng} / \mathrm{mL}\right)$ was compared with low-dose cyclosporine (C2, 350-500 ng/mL) and lowdose everolimus $\left(\mathrm{C}_{\text {min }}, 3-8 \mathrm{ng} / \mathrm{mL}\right)$. All patients received basiliximab and prednisone. Overlapping C2 cyclosporine concentrations between the two study arms prevented a final conclusion on the superiority of one strategy over the other in terms of preservation of renal function. On the other hand, because there was no statistical difference when comparing the incidence of biopsy-proven acute rejection and renal function (Tables 1 and 2), this study provided evidence for use of alternative strategies for individual patients. ${ }^{65}$

More recently, a prospective study (A2420) in kidney transplant patients at higher risk of developing delayed graft function who received basiliximab induction, cyclosporine, and corticosteroids showed a similar incidence of biopsyproven acute rejection comparing patients with immediate (day 1) or delayed (week 5, conversion from mycophenolic acid) introduction of everolimus (20.0\% versus $20.3 \%$ ). Renal function at one year was also similar in both groups (Tables 1 and 2). ${ }^{66}$

\section{Everolimus combined with tacrolimus in de novo kidney transplantation}

Because the use of tacrolimus in de novo kidney transplant recipients has increased substantially, studies were conducted to investigate optimal dosing in combination with everolimus. Based on the previous experience with cyclosporine, the first exploratory study compared full and reduced tacrolimus exposures in combination with everolimus in patients receiving basiliximab induction and steroids. Initial everolimus dose was $0.75 \mathrm{mg}$ twice daily, adjusted to obtain an everolimus $\mathrm{C}_{\min }$ of 3-12 ng/mL. No differences were observed in the incidence of biopsy-proven acute rejection or in renal function, mainly because tacrolimus exposures were similar in both groups (Tables 1 and 2). ${ }^{67}$ Patients with a mean everolimus $\mathrm{C}_{\min }$ below $3 \mathrm{ng} / \mathrm{mL}$ had a higher incidence of biopsy-proven acute rejection compared with those with a mean everolimus $\mathrm{C}_{\min }$ of $3-8 \mathrm{ng} / \mathrm{mL}$ or above $8 \mathrm{ng} / \mathrm{mL}$. The proportion of African Americans in the group of patients who had trough everolimus concentrations less than $3 \mathrm{ng} /$ $\mathrm{mL}$ was significantly higher compared with that in the other two groups. No correlation was observed between everolimus $\mathrm{C}_{\min }$ and renal function. ${ }^{68}$

To investigate the potential benefit of further reductions in tacrolimus exposure, a 12-month, prospective, multicenter study was conducted. In this study, patients received basiliximab induction, everolimus $1.5 \mathrm{mg}$ twice daily (everolimus $\mathrm{C}_{\min } 3-8 \mathrm{ng} / \mathrm{mL}$ ) and low-dose tacrolimus (4-7 ng/mL), and were randomized to undergo (very low-dose tacrolimus) or not to undergo (low-dose tacrolimus) further reduction in tacrolimus exposure $(1.5-3.0 \mathrm{ng} / \mathrm{mL})$ after the third month. ${ }^{69}$ Unexpectedly, the incidence of biopsy-proven acute rejection was higher in the very low-dose tacrolimus group during the first three months $(18.7 \%$ versus $7.7 \% ; P=0.0138)$ when tacrolimus concentrations were comparable between the two groups. Between months 4 and 12, both groups showed a similar incidence of biopsy-proven acute rejection $(2.7 \%$ versus $1.1 \% ; P=0.165$ ), respectively (Table 1 ). Slightly superior renal function was achieved in patients from the very lowdose tacrolimus group (Table 2). At months $6(3.5 \mathrm{ng} / \mathrm{mL})$, $9(3.4 \mathrm{ng} / \mathrm{mL})$, and $12(3.4 \mathrm{ng} / \mathrm{mL})$, tacrolimus exposures in the very low-dose tacrolimus groups were higher than that recommended by the protocol. ${ }^{69}$ Although it seems possible that tacrolimus concentrations below $4 \mathrm{ng} / \mathrm{mL}$ may be effective in combination with everolimus, the lack of an active and adequate comparator group, perhaps using low exposure tacrolimus and mycophenolate mofetil/cyclosporine, and mycophenolate sodium, preclude any robust risk/benefit evaluation at this point.

\section{Conversion to everolimus in maintenance kidney transplant recipients}

Two clinical considerations have been the leading reasons to switch patients from calcineurin inhibitors to mTOR inhibitors after kidney transplantation. The first and predominant one is to preserve renal function. Because of the perceived contribution of chronic use of calcineurin inhibitors to the development of chronic allograft nephropathy, ${ }^{70}$ the leading cause of graft loss after kidney transplantation, there is now considerable and growing interest in calcineurin inhibitor-sparing immunosuppressive regimens. ${ }^{71}$ The second 
one is related to the management of patients with a previous history of or current malignancies. ${ }^{72}$

\section{Preservation of allograft function}

Although a substantial amount of conversion strategies using sirolimus have been reported, little data are currently available for everolimus. Several single-center uncontrolled studies have investigated the efficacy and safety of conversion from a calcineurin inhibitor to everolimus in kidney transplant recipients. The majority of studies included only stable patients with good renal function and without significant proteinuria. A few studies attempted to use everolimus in patients with chronic allograft dysfunction. Most studies proposed an abrupt conversion strategy, but others have suggested a gradual reduction of the calcineurin inhibitor dose, with one study maintaining patients on an $80 \%$ calcineurin inhibitor dose reduction. The preferred initial everolimus dose was $1.5 \mathrm{mg}$ twice daily, with proposed target blood everolimus concentrations in the $3-10 \mathrm{ng} / \mathrm{mL}$ range. The incidence of acute rejection after conversion varied from $0 \%$ to $17 \%$ according to different strategies. Renal function either improved or remained stable. While dyslipidemia was observed in the majority of studies, proteinuria was not consistently observed. ${ }^{73-80}$

A retrospective review of registry data for 272 patients followed for six months after introduction of everolimus was reported after approval of everolimus in Europe in 2005. Everolimus was preferentially introduced as a conversion strategy $(93.8 \%)$ after the first month of transplantation. Six months after conversion, $75 \%$ of patients were off calcineurin inhibitors. Prevention and/or treatment of toxicities, especially nephrotoxicity, accounted for $46.3 \%$ of the indications for everolimus. Initial mean doses were $1.37 \mathrm{mg} /$ day, increased to $2 \mathrm{mg}$ /day at six months. Renal function remained unchanged during the follow-up period, whereas proteinuria increased. Five (2\%) episodes of acute rejection were observed, with excellent patient and graft survivals at six months after conversion. ${ }^{81}$

In a multicenter, prospective, randomized trial, low- to moderate-risk patients received basiliximab induction, cyclosporine, cyclosporine and mycophenolate sodium, and prednisolone after transplantation. Patients with good graft function (glomerular filtration rate $>20 \mathrm{~mL} / \mathrm{min}$ ), without severe rejection within the previous four weeks, and without subclinical rejection at a protocol biopsy after six months $(n=113)$ underwent either mycophenolate sodium withdrawal over 14 days (cyclosporine group $n=39$ ), cyclosporine withdrawal over 14 days (mycophenolate sodium group, $\mathrm{n}=36$ ) or abrupt conversion from cyclosporine to everolimus followed by withdrawal of mycophenolate sodium over 14 days (EVR group, $\mathrm{n}=38$ ). Doses of cyclosporine, mycophenolate sodium or everolimus were adjusted to obtain predefined target AUC concentrations. Doses of cyclosporine, mycophenolate sodium, or everolimus were adjusted to obtain predefined target AUC concentrations. Prednisolone was temporarily increased to minimize the risk of rejection because of pharmacokinetic fluctuations. After a mean follow-up of $8 \pm 5$ months after intervention, the incidence of acute rejection was $3 \%$ in the cyclosporine group, $22 \%$ in the mycophenolate sodium group, and $0 \%$ in the everolimus group $(P<0.009)$. Mean creatinine values at the latest follow-up were lower in the everolimus group than in the cyclosporine group. No significant differences were observed in lipids, hematology, or proteinuria. However, side effects occurred significantly more often in the everolimus group. ${ }^{82}$

In a German prospective, open-label, multicenter, controlled study, 300 renal allograft recipients receiving basiliximab induction, cyclosporine, mycophenolate sodium, and steroids were randomized at 4.5 months to undergo conversion from cyclosporine to everolimus $(n=155)$ or to be maintained on the original regimen $(n=145)$. The initial everolimus dose was twice daily, targeting trough blood concentrations of 6-10 ng/mL. Renal function (calculated glomerular filtration rate) was comparable at 4.5 months $\left(64.2 \pm 17.4\right.$ versus $\left.63.0 \pm 15.5 \mathrm{~mL} / \mathrm{min} / \mathrm{m}^{2}\right)$, improving in the conversion group at 24 months $(68.9 \pm 19.4$ versus $\left.61.7 \pm 17.1 \mathrm{~mL} / \mathrm{min} / \mathrm{m}^{2} ; P<0.017\right)$. The incidence of biopsy-proven acute rejection was higher among patients in the conversion group (11\% versus $4.8 \%)$. Three deaths and one graft loss were observed in the cyclosporine group and none in the everolimus group. The cumulative incidences of infections (22.6\% versus $20.7 \%)$ and hospitalizations $(27.7 \%$ versus $35.2 \%$ ) were similar. ${ }^{83}$

In a prospective, open-label, multicenter, controlled study conducted in Spain, 195 renal allograft recipients receiving tacrolimus, mycophenolate sodium, and steroids were randomized at three months to undergo a conversion from tacrolimus to everolimus or to be maintained on the original regimen. To undergo randomization and treatment allocation, patients had to show a serum creatinine lower than $2.5 \mathrm{mg} / \mathrm{dL}$, proteinuria lower than $1 \mathrm{~g} /$ day, no previous biopsy-proven acute rejection (either severe grade or any grade in the prerandomization biopsy). An interim analysis six months after randomization including 50 patients in the control group (tacrolimus) and 51 in the conversion group (everolimus) showed no differences in renal function 
( 51.1 versus $55.2 \mathrm{~mL} / \mathrm{min} ; P=0.24$ ) or proteinuria (100 versus $140 \mathrm{mg} / \mathrm{dL}$ ). The incidence of biopsy-proven acute rejection after conversion to everolimus was $13.7 \%$. A higher incidence of cytomegalovirus infection was observed in the tacrolimus group (12.2 versus $3.4 \% ; P=0.01) .{ }^{84}$

\section{Management of malignancies}

Several series have demonstrated the effectiveness of conversion from a calcineurin inhibitor to everolimus in patients with nonmelanoma skin cancer, ${ }^{85,86}$ Kaposi's sarcoma, ${ }^{87}$ posttransplant lymphoproliferative disorders, ${ }^{88}$ and other types of malignancies. ${ }^{89}$ The mechanisms of antineoplastic effects in vitro, effects in animal models, ${ }^{90}$ and the reported initial clinical experience with mTOR inhibitors led European and Australian investigators to develop a clinical guideline for use of mTOR inhibitors in the management of post-transplant malignancies. ${ }^{91}$

\section{Other}

There are a few reports on conversion from sirolimus to everolimus. The most common reason for this switch was the occurrence of an adverse reaction, mainly aphthous ulcers or pneumonitis, in patients receiving sirolimus. ${ }^{92,93}$ In a six-month prospective, open-label pilot study, maintenance renal transplant patients receiving sirolimus, mycophenolate sodium, and corticosteroids were converted to everolimus $8 \mathrm{mg} /$ day $(8-15 \mathrm{ng} / \mathrm{mL}$ ) and followed for six months. This pilot study suggests that this strategy is safe and easily manageable, but there was no consistent evidence for a change in glomerular filtration rate or proximal renal allograft tubular function. $^{94}$

\section{Safety and tolerability}

Study drug discontinuation may be used as a direct measure of the safety and tolerability of a treatment regimen. In trials conducted in kidney transplant recipients, the main reason for study drug discontinuation is the occurrence of an adverse event. In the majority of prospective trials (double-blind or open-label) the rate of discontinuation of everolimus was higher than for the active comparator drug. There are confounding factors precluding a direct analysis and conclusion from these studies. First, investigators may have less knowledge and experience to manage adverse events related to the experimental regimen (leading to more discontinuations) as opposed to the control one (leading to more dose adjustments and temporary interruptions). In the A2309 trial, when considering adverse events leading to study drug discontinuation or study drug dose adjustment or interruption, the incidence was $36.5 \%$ for everolimus $0.75 \mathrm{mg}$ twice daily, $47.1 \%$ for everolimus $1.5 \mathrm{mg}$ twice daily, and $43.6 \%$ for cyclosporine and mycophenolate sodium. ${ }^{64}$ Selected safety and tolerability parameters from prospective multicenter trials are shown in Table 4.

\section{Initial renal allograft function and surgical wound healing}

The use of mTOR inhibitors immediately after kidney transplantation has been limited by data indicating that the antiproliferative effects of these immunosuppressive agents may delay recovery from ischemia-reperfusion injury and proper wound healing. In animal models, recovery from renal ischemia-reperfusion injury ${ }^{95}$ may be aggravated by the antiproliferative effect of mTOR inhibitors on renal tubular cells. ${ }^{96}$

Reports from single-center studies indicate that sirolimus is associated with an increased incidence ${ }^{97}$ and/or duration of delayed graft function. ${ }^{98}$ In the 2309 study, the incidence of delayed graft function in patients receiving everolimus $0.75 \mathrm{mg}$ or $1.5 \mathrm{mg}$ twice daily was similar to that observed in patients receiving cyclosporine and mycophenolate sodium (10.2\% versus $10.4 \%$ versus $9.2 \%)$, respectively. ${ }^{64}$ Nevertheless, this effect may be more evident in patients with higher risk of developing delayed graft function.

In a prospective kidney transplant study including patients at higher risk of developing delayed graft function and receiving cyclosporine, corticosteroids, and interleukin- 2 receptor antagonist antibody induction, a similar low rate of delayed graft function was observed comparing patients with immediate or delayed introduction of everolimus $(24.6 \%$ versus $24.3 \%$, respectively). Furthermore, the incidence of slow graft function $(38.5 \%$ and $47.2 \%)$ and rate of recovery of renal function and glomerular filtration rate at three months $\left(52.7 \pm 20.4\right.$ versus $\left.48.8 \pm 19.6 \mathrm{~mL} / \mathrm{min} / 1.73 \mathrm{~m}^{2}\right)$ were not different comparing patients with immediate or delayed introduction of everolimus. ${ }^{99}$

A higher incidence of wound healing complications after kidney transplantation has been described for both sirolimus $^{100,101}$ and everolimus. Early clinical trials (B201, B251) already indicated an increase incidence of lymphocele in kidney transplant patients receiving fixed-dose everolimus versus mycophenolate mofetil. ${ }^{51}$ The A2309 study prospectively and systematically investigated wound healing events, confirming the initial impression of a higher incidence in patients receiving everolimus. ${ }^{64}$ On the other hand, a cross-study comparison of everolimus versus mycophenolate mofetil observed tissue regeneration to be similar 
Table 4a Safety and tolerability of everolimus regimens

\begin{tabular}{|c|c|c|c|c|c|c|c|}
\hline Study ID & Study groups & $\begin{array}{l}\text { Overall } \\
\text { study drug } \\
\text { discontinuation (\%) }\end{array}$ & $\begin{array}{l}\text { Study drug } \\
\text { discontinuation } \\
\text { due to AEs }(\%)\end{array}$ & SAE (\%) & DGF (\%) & $\begin{array}{l}\text { Wound healing } \\
\text { events (\%) }\end{array}$ & Malignancy (\%) \\
\hline \multirow[t]{3}{*}{$\mathrm{B} 20 \mathrm{I}^{52}$} & $\mathrm{CsA}_{\mathrm{f}}+\mathrm{EVR} 0.75 \mathrm{mg}$ bid & 50.5 & 31.0 & 71.0 & 23.0 & 9.0 & 5.2 \\
\hline & $\mathrm{CsA}_{\mathrm{f}}+\mathrm{EVR} \mathrm{I} .5 \mathrm{mg}$ bid & 57.1 & 28.0 & 75.0 & 21.0 & 12.0 & 4.5 \\
\hline & $\mathrm{CsA}_{\mathrm{f}}+\mathrm{MMF}$ I g bid & 41.3 & 39.0 & 62.0 & 20.0 & 4.0 & 4.6 \\
\hline \multirow[t]{3}{*}{$B 25 I^{53}$} & $\mathrm{CsA}_{\mathrm{f}}+\mathrm{EVR} 0.75 \mathrm{mg}$ bid & 56.5 & na & na & na & 16.1 & 4.7 \\
\hline & $\mathrm{CsA}_{\mathrm{f}}+\mathrm{EVR} \mathrm{I.5} \mathrm{mg}$ bid & 64.9 & na & na & na & 18.6 & 5.2 \\
\hline & $\mathrm{CsA}_{\mathrm{f}}+\mathrm{MMF}$ I g bid & 45.4 & na & na & na & 12.2 & 6.1 \\
\hline \multirow[t]{2}{*}{$\mathrm{B} 156^{59}$} & $\mathrm{CsA}_{\mathrm{f}}+\mathrm{EVR} 1.5 \mathrm{mg}$ bid & 54.7 & 39.6 & 84.9 & na & na & 3.8 \\
\hline & $\mathrm{CsA}_{\mathrm{r}}+\mathrm{EVR} \mathrm{I} .5 \mathrm{mg}$ bid & 32.8 & 17.2 & 77.6 & na & na & 5.1 \\
\hline \multirow[t]{2}{*}{$A 2306^{63}$} & $\mathrm{CsA}_{\mathrm{r}}+$ EVR $0.75 \mathrm{mg}$ bid & $26.8^{\#}$ & $18.8^{\#}$ & na & 14.0 & 15.2 & 1.8 \\
\hline & $\mathrm{CsA}_{r}+$ EVR I.5 mg bid & 20.0 & 10.4 & na & 16.8 & 8.0 & 1.6 \\
\hline \multirow[t]{2}{*}{$A 2307^{63}$} & $\mathrm{CsA}_{\mathrm{r}}+\mathrm{EVR} 0.75 \mathrm{mg}$ bid & $18.8^{\#}$ & $12.0^{\#}$ & na & 19.7 & 10.3 & 2.6 \\
\hline & $\mathrm{CsA}_{\mathrm{r}}+\mathrm{EVR} \mathrm{I} .5 \mathrm{mg}$ bid & 15.8 & 9.4 & na & 20.1 & 7.2 & 2.2 \\
\hline \multirow[t]{3}{*}{ B230964 } & $\mathrm{CsA}_{\mathrm{r}}+\mathrm{EVR} 0.75 \mathrm{mg}$ bid & 30.0 & 23.4 & 56.6 & 10.2 & 35.0 & 3.3 \\
\hline & $\mathrm{CsA}_{\mathrm{r}}+\mathrm{EVR} \mathrm{I} .5 \mathrm{mg}$ bid & 34.9 & 28.4 & 60.4 & 10.4 & 38.8 & 2.9 \\
\hline & $\mathrm{CsA}_{\mathrm{f}}+$ MPA $720 \mathrm{mg}$ bid & 21.7 & 15.8 & 53.8 & 9.2 & 25.6 & 5.9 \\
\hline \multirow[t]{2}{*}{ EVLEC $^{65}$} & $\mathrm{CsA}_{r}+\mathrm{EVR}_{s}$ & 21.8 & 17.5 & 52.5 & 30.8 & 15.4 & 1.4 \\
\hline & $\mathrm{CsA}_{\mathrm{vl}}+\mathrm{EVRR}_{\mathrm{h}}$ & 21.0 & 23.5 & 50.1 & 23.2 & 21.1 & 1.4 \\
\hline \multirow[t]{2}{*}{$A 2420^{66}$} & $\mathrm{CsA}_{\mathrm{r}}+\mathrm{EVR}$ & 32.3 & 26.2 & 69.2 & 24.6 & 40.0 & 1.5 \\
\hline & $\begin{array}{l}\mathrm{CsA}_{\mathrm{f}}+\mathrm{MPA} \rightarrow \mathrm{EVR} \\
0.75 \mathrm{mg} \text { bid }\end{array}$ & 48.6 & 35.1 & 77.0 & 24.3 & 37.8 & 5.4 \\
\hline \multirow[t]{2}{*}{ CRADUSO ${ }^{67}$} & $\mathrm{TAC}_{\mathrm{r}}+\mathrm{EVR} 1.5 \mathrm{mg}$ bid & 12.2 & 10.2 & 22.0 & 8.2 & 10.0 & 0.0 \\
\hline & $\mathrm{TAC}_{\mathrm{f}}+\mathrm{EVR} \mathrm{I} .5 \mathrm{mg}$ bid & 25.6 & 9.0 & 33.0 & 9.3 & 9.3 & 2.3 \\
\hline \multirow[t]{2}{*}{ ASSET $^{68}$} & 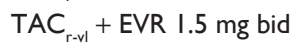 & 23.4 & 11.9 & 58.7 & na & 17.4 & 0.0 \\
\hline & $\mathrm{TAC}_{\mathrm{r}}+\mathrm{EVR} 1.5 \mathrm{mg}$ bid & 19.8 & 6.7 & 51.3 & na & 21.0 & 0.9 \\
\hline
\end{tabular}

Notes: Definitions and criteria of these selected events vary between studies. B20I, B25I, and BI56: incidences at three years; the other studies incidences are at one year. \#Incidences at six months.

Abbreviations: EVR, everolimus; CsA, full cyclosporine exposure; CsA, reduced cyclosporine exposure; CsA, very low cyclosporine exposure; EVRs, standard

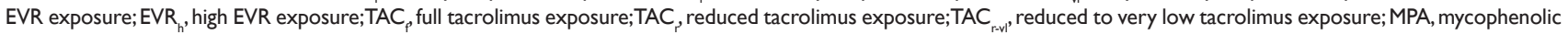
acid; MMF, mycophenolate mofetil; MPA, mycophenolate acid;AEs, adverse events; SAE, serious adverse events; DGF, delayed graft function; na, not available; bid, twice daily.

with either agent after kidney transplantation. ${ }^{102}$ Furthermore, no differences in wound healing events were observed in another prospective study comparing immediate versus delayed introduction of everolimus. ${ }^{99}$

The contrasting clinical observations for the incidence of delayed graft function and wound healing complications across different studies and using different mTOR inhibitors (sirolimus or everolimus) may involve several donor and recipient risk factors and mTOR blood concentrations.

\section{Proteinuria}

The development of proteinuria has been observed in kidney transplant patients on mTOR inhibitor treatment. ${ }^{103} \mathrm{~A}$ higher incidence of proteinuria has been seen in kidney transplant recipients receiving everolimus. This was observed when everolimus was combined with full doses of cyclosporin ${ }^{53}$ and with progressive reduction in cyclosporine exposure. ${ }^{64}$ In the B251 trial, by 36 months, values of $1000 \mathrm{mg} /$ day were observed in $11 \%$ versus $2 \%$ in the everolimus and mycophenolic acid groups, respectively. ${ }^{53}$ In another trial (A2309), the incidence of subnephrotic proteinuria (urinary protein:creatinine ratio $300-3000 \mathrm{mg} / \mathrm{g}$ ) at month 12 in the everolimus group was twice that in the mycophenolic acid group (24\% versus $12.7 \%$ ). There is also a dose effect, and patients receiving higher doses of everolimus (1.5 mg twice daily) show a higher incidence and magnitude of proteinuria. ${ }^{64}$

mTOR inhibitors may alter the behavior and integrity of glomerular podocytes. The use of these drugs immediately after kidney transplantation or as a conversion strategy decreased the expression of nephrin within the glomerulus, a critical component of the glomerular slit-diaphragm, and increased proteinuria in some but not all patients. This effect was not observed in biopsies from control transplant patients not treated with mTOR inhibitors. Whether there is a direct correlation between mTOR concentrations, decreased expression of nephrin, and proteinuria is not known. ${ }^{104}$ 
Table $4 b$ Safety and tolerability of everolimus regimens

\begin{tabular}{|c|c|c|c|c|c|c|}
\hline Study ID & Study groups & CMV (\%) & NODAT (\%) & Proteinuria (\%) & $\begin{array}{l}\text { Peripheral } \\
\text { edema (\%) }\end{array}$ & Diarrhea (\%) \\
\hline \multirow[t]{3}{*}{ B20I } & $\mathrm{CsA}_{\mathrm{f}}+\mathrm{EVR} 0.75 \mathrm{mg}$ bid & 5.7 & 6.7 & na & 19.6 & 24.7 \\
\hline & $\mathrm{CsA}_{\mathrm{f}}+\mathrm{EVR} 1.5 \mathrm{mg}$ bid & 8.1 & 12.6 & na & 22.2 & 20.7 \\
\hline & $\mathrm{CsA}_{\mathrm{f}}+\mathrm{MMF} \mathrm{I} \mathrm{g}$ bid & 19.9 & 6.6 & na & 17.3 & 16.3 \\
\hline \multirow[t]{3}{*}{ B25I } & $\mathrm{CsA}_{\mathrm{f}}+\mathrm{EVR} 0.75 \mathrm{mg}$ bid & 5.2 & na & 39.5 & 52.3 & 31.6 \\
\hline & $\mathrm{CsA}_{\mathrm{f}}+\mathrm{EVR} 1.5 \mathrm{mg}$ bid & 4.1 & na & 39.2 & 47.4 & 35.6 \\
\hline & $\mathrm{CsA}_{f}+\mathrm{MMF}$ I g bid & 6.1 & na & 14.9 & 41.8 & 30.6 \\
\hline \multirow[t]{2}{*}{ BI56 } & $\mathrm{CsA}_{\mathrm{f}}+$ EVR I.5 mg bid & 11.3 & na & 9.4 & na & 32.1 \\
\hline & $\mathrm{CsA}_{\mathrm{r}}+$ EVR I.5 mg bid & 3.4 & na & 22.4 & na & 19.0 \\
\hline \multirow[t]{2}{*}{ A2306 } & $\mathrm{CsA}_{r}+\mathrm{EVR} 0.75 \mathrm{mg}$ bid & $0.9^{\#}$ & 10.7 & na & na & $16 . I^{\#}$ \\
\hline & $\mathrm{CsA}_{\mathrm{r}}^{\mathrm{r}}+\mathrm{EVR} 1.5 \mathrm{mg}$ bid & 3.2 & 10.4 & na & na & 8.0 \\
\hline \multirow[t]{2}{*}{ A2307 } & $\mathrm{CsA}_{\mathrm{r}}+\mathrm{EVR} 0.75 \mathrm{mg}$ bid & $2.6^{\#}$ & 8.6 & na & na & $12.8^{\#}$ \\
\hline & $\mathrm{CsA}_{\mathrm{r}}+\mathrm{EVR} 1.5 \mathrm{mg}$ bid & 2.2 & 8.6 & na & na & 12.9 \\
\hline \multirow[t]{3}{*}{ B2309 } & $\mathrm{CsA}_{\mathrm{r}}+\mathrm{EVR} 0.75 \mathrm{mg}$ bid & 2.9 & 5.1 & 9.1 & 44.9 & na \\
\hline & $\mathrm{CsA}_{\mathrm{r}}+\mathrm{EVR} 1.5 \mathrm{mg}$ bid & 2.1 & 7.9 & 12.9 & 43.2 & na \\
\hline & $\mathrm{CsA}_{\mathrm{f}}+\mathrm{MPA} 720 \mathrm{mg}$ bid & 12.5 & 7.0 & 7.3 & 39.6 & na \\
\hline \multirow[t]{2}{*}{ EVLEC } & $\mathrm{CsA}_{r}+\mathrm{EVR}_{s}$ & na & 2.1 & na & na & 11.2 \\
\hline & $\mathrm{CsA}_{\mathrm{vl}}+\mathrm{EVR}_{\mathrm{h}}$ & na & 4.9 & na & na & 9.9 \\
\hline \multirow[t]{2}{*}{ A2420 } & $\mathrm{CsA}_{r}+\mathrm{EVR}$ & 1.5 & na & 12.3 & 40.0 & na \\
\hline & $\mathrm{CsA}_{\mathrm{f}}+\mathrm{MPA} \rightarrow \mathrm{EVR} 0.75 \mathrm{mg}$ bid & 6.8 & na & 9.5 & 56.8 & na \\
\hline \multirow[t]{2}{*}{ CRADUS09 } & $\mathrm{TAC}_{\mathrm{r}}+\mathrm{EVR} 1.5 \mathrm{mg}$ bid & na & 38 & 0.0 & 47.0 & 36.7 \\
\hline & $\mathrm{TAC}_{\mathrm{f}}+\mathrm{EVR} \mathrm{I.5} \mathrm{mg}$ bid & na & 24 & 2.3 & 20.9 & 30.2 \\
\hline \multirow[t]{2}{*}{ ASSET } & $\mathrm{TAC}_{\mathrm{rvvl}}+\mathrm{EVR} \mathrm{I} .5 \mathrm{mg}$ bid & 1.8 & 17.8 & 11.0 & 23.9 & 15.6 \\
\hline & $\mathrm{TAC}_{\mathrm{r}}^{\mathrm{r}-\mathrm{vl}}+\mathrm{EVR} 1.5 \mathrm{mg}$ bid & 2.8 & 20.5 & 7.6 & 23.5 & 16.0 \\
\hline
\end{tabular}

Notes: "Incidences at six months. Definitions and criteria of these selected events vary between studies. B20I, B25I, and BI56: incidences at three years; the other studies incidences are at one year; ${ }^{\#} P<0.05$ versus EVR $0.75 \mathrm{mg}$ bid.

Abbreviations: CMV, cytomegalovirus; NODAT, new-onset diabetes after transplantation; na, not available; EVR, everolimus; CsA full cyclosporine exposure; $\mathrm{Cs}_{\mathrm{r}}$, reduced cyclosporine exposure; $\mathrm{Cs}_{\mathrm{v}}$, very low cyclosporine exposure; EVR, standard EVR exposure; EVR, high EVR exposure; TAC, full tacrolimus exposure; $\mathrm{TAC}_{\mathrm{r}}$, reduced tacrolimus exposure; $\mathrm{TAC}_{\mathrm{r}-\mathrm{v}}$, reduced to very low tacrolimus exposure; MPA, mycophenolic acid; MMF, mycophenolate mofetil; MPA, mycophenolate acid; bid, twice daily.

\section{Metabolic adverse events}

Dyslipidemia is common in kidney transplant recipients. Cyclosporine, steroids, and mTOR inhibitors are directly involved in the incidence and magnitude of this adverse reaction. ${ }^{105}$ In the majority of studies, mean cholesterol and triglyceride concentrations were higher among patients receiving everolimus compared with those receiving mycophenolate mofetil or mycophenolate sodium, despite a higher proportion of patients receiving lipid-lowering agents. Hypercholesterolemia and hypertriglyceridemia peaks at two to three months after transplantation, stabilizing or decreasing thereafter. This finding may be related to an increased use of lipid-lowering agents, reduction in dose of everolimus and and/or steroids, or discontinuation of everolimus treatment. ${ }^{106}$ Furthermore, because of the relatively low number of patients treated with everolimus and the short duration of follow-up thus far, it is difficult to assess the impact of dyslipidemia on cardiovascular disease in kidney transplant recipients receiving everolimus.
New-onset diabetes after transplantation (NODAT) is associated with inferior patient and graft survival. ${ }^{107}$ The use of mTOR inhibitors may be associated with an increased incidence of NODAT. A registry analysis including 20,124 adult recipients of a first kidney transplant and without diabetes demonstrated that sirolimus-treated patients were at an increased risk for NODAT. This risk was higher when sirolimus was used in combination with cyclosporine or tacrolimus compared with mycophenolate mofetil or azathioprine. ${ }^{108}$ In the most recent everolimus study, the incidence of NODAT was $9.1 \%$ versus $12.2 \%$ versus $6.6 \%$ in patients receiving everolimus $0.75 \mathrm{mg}$ twice daily, $1.5 \mathrm{mg}$ twice daily, or mycophenolate sodium, respectively. ${ }^{64}$

\section{Viral infections}

Cytomegalovirus infection/disease has been associated with acute rejection, chronic graft dysfunction, increased risk of opportunistic infections, and synergistic effects with other agents to cause disease (Epstein-Barr virus and post-transplant lymphoproliferative disorders, 


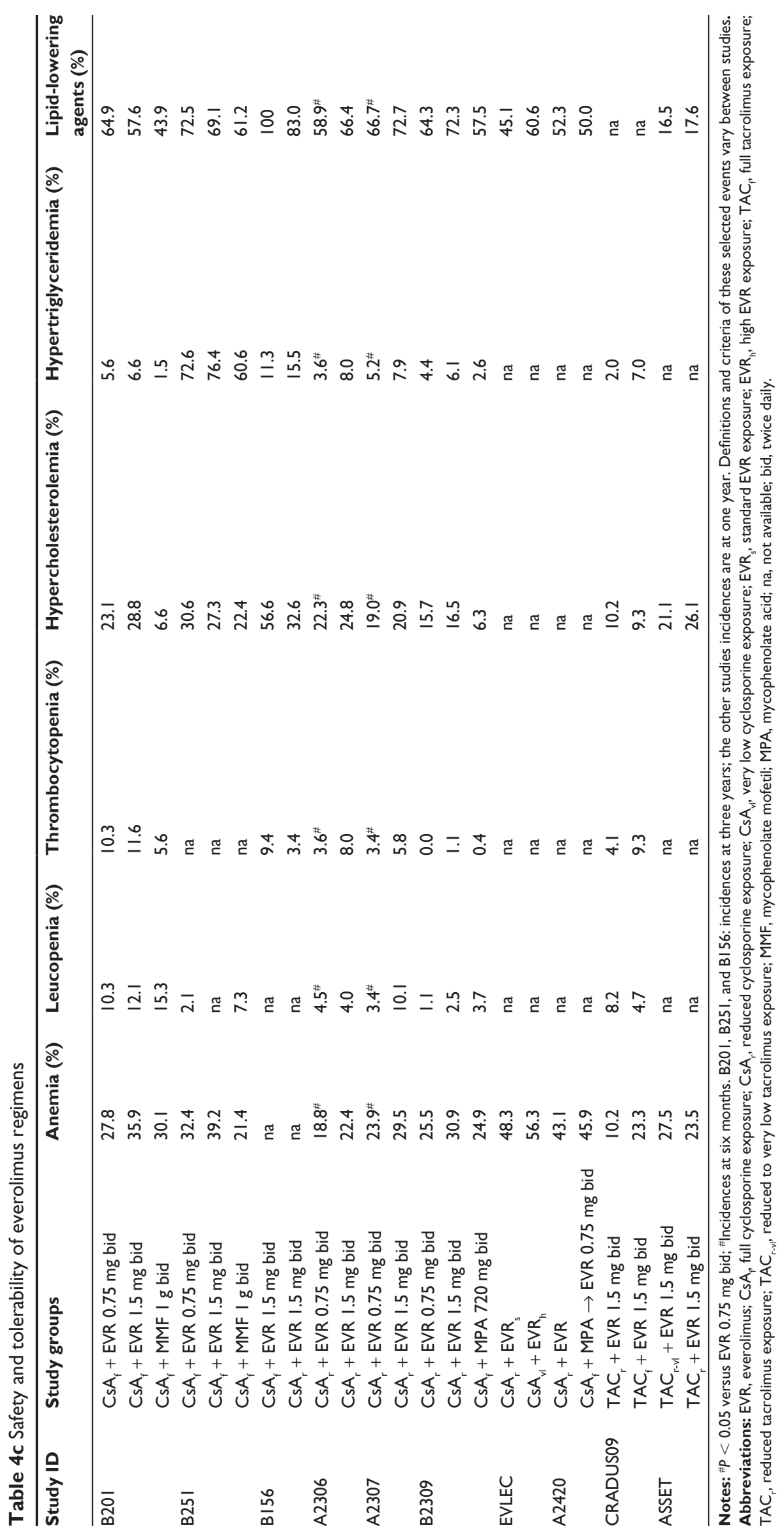


viral syndromes and graft loss with human herpes viruses 6 and 7). Cytomegalovirus disease also appears to be an independent risk factor for patient and graft survival. ${ }^{109}$

In a meta-analysis of 33 trials (27 of sirolimus, five of everolimus, and one head-to-head comparison), patients receiving mTOR inhibitors replacing mycophenolate mofetil/ mycophenolate sodium/azathioprine had a $51 \%$ reduction in the risk of developing cytomegalovirus infection. ${ }^{110}$ In another study involving 1398 renal transplant recipients, a maintenance regimen containing sirolimus was independently associated with a $84 \%$ lower risk of cytomegalovirus infection. ${ }^{111}$ In two everolimus studies, the incidence of cytomegalovirus infection was lower among patients receiving everolimus. ${ }^{52,64,112}$ In the A2309 study, the incidences of cytomegalovirus infection $(0.7 \%, 0.0 \%$, and $5.9 \%)$, syndrome $(1.5 \%, 1.4 \%$, and $4.4 \%)$, and disease $(0.7 \%, 0.7 \%$, and $2.2 \%$ ) were higher among patients receiving mycophenolate sodium. ${ }^{64,112}$

The prevalence of polyoma virus-associated nephropathy in renal transplant recipients varies from $1 \%$ to $10 \%$, reflecting differences in intensity of immunosuppressive regimens and in diagnostic approaches. The prognosis is poor, with progressive deterioration of allograft function and return to dialysis in at least $50 \%$ of cases in the early years. ${ }^{113}$ In the A2309 trial, patients receiving everolimus showed a lower incidence of BK viruria ( 0.7 versus 0.4 versus 3.3$)$, viremia (1.1 versus 0.7 versus 1.8$)$ and nephropathy ( 0.4 versus 0.0 versus 0.7 ) compared with those receiving mycophenolate sodium. ${ }^{64,112}$

\section{Cyclosporine-related adverse events}

The A2309 study showed that reduced cyclosporine exposure in combination with everolimus resulted in a lower incidence of cyclosporine-related adverse events (tremor, gingival hyperplasia, gingival hypertrophy, and hirsutism) compared with standard cyclosporine exposure in combination with mycophenolate sodium. ${ }^{64}$

\section{Thrombotic events}

Inhibitors of mTOR have been associated with thrombotic microangiopathic events, whether combined with a calcineurin inhibitor or not. ${ }^{114}$ In one registry analysis, risk factors for de novo thrombotic microangiopathy included younger recipient age, older donor age, female gender, and initial use of sirolimus. ${ }^{115}$ Production of vascular endothelial growth factor in podocytes is required for survival of glomerular endothelial cells. Alteration of vascular endothelial growth factor podocyte production is one mechanism by which sirolimus may increase the risk of renal thrombotic microangiopathy. ${ }^{116}$

In the B201 trials, hemolytic uremic syndrome was the cause of discontinuation of treatment in $4 \%$ of patients receiving everolimus $1.5 \mathrm{mg}$ twice daily. ${ }^{51}$ In the B251 trial, the incidence of hemolytic uremic syndrome was $2.5 \%$ in the everolimus $0.75 \mathrm{mg}$ twice daily group, $1.5 \%$ in the everolimus $1.5 \mathrm{mg}$ twice daily group, and $0.5 \%$ in the mycophenolate mofetil group. An additional patient receiving everolimus $1.5 \mathrm{mg}$ twice daily developed thrombotic thrombocytopenic purpura. ${ }^{53}$ In the A2306/A2307 trials, three patients receiving everolimus $0.75 \mathrm{mg}$ twice daily and one on $1.5 \mathrm{mg}$ twice daily developed hemolytic uremic syndrome. ${ }^{62}$ Two additional patients were reported to develop hemolytic uremic syndrome in other studies. ${ }^{65,69}$ In the A2309 study, three serious adverse events (on days 1, 6, and 115) were reported, including hemolytic uremic syndrome, thrombotic microangiopathy, and thrombotic thrombocytopenic purpura ${ }^{64}$ While calcineurin inhibitors may cause or aggravate endothelial lesions through their pronecrotic, vasoactive, and profibrotic activity, mTOR inhibitors may delay repair of the endothelial damage by interference with endothelial growth factor. ${ }^{117}$ Therefore, the increased incidence of hemolytic uremic syndrome could be related to the known biological synergy with cyclosporine, thus exacerbating calcineurin inhibitorinduced endothelial damage. ${ }^{118}$

Furthermore, there is a concern as to whether graft loss due to thrombosis is more frequent among patients receiving mTOR inhibitors. A pooled analysis of three prospective randomized studies (B201, B251, and A2309) revealed that the incidence of graft loss due to thrombosis was similar (1.66\% versus $1.34 \%$ versus $1.5 \%)$ in patients receiving everolimus $0.75 \mathrm{mg}$ twice daily, everolimus $1.5 \mathrm{mg}$ twice daily, or mycophenolate mofetil/mycophenolate sodium, respectively. ${ }^{119}$

\section{Hematology}

The most frequent hematological adverse event in the everolimus trials was anemia. ${ }^{52,53,62}$ In the A2309 study, the incidences were $26.6 \%$ versus $33.8 \%$ versus $27.5 \%$ for everolimus $0.75 \mathrm{mg}$ twice daily, everolimus $1.5 \mathrm{mg}$ twice daily, or mycophenolate mofetil/mycophenolate sodium, respectively. The use of erythropoietin-stimulating agents was also similar (27.7\% versus $29.9 \%$ versus $26.4 \%$ ). Leucopenia $(2.9 \%$ versus $2.2 \%$ versus $12.1 \%)$ appeared to be more frequent among patients receiving mycophenolate mofetil/ mycophenolate sodium. ${ }^{64}$ 


\section{Malignancies}

In randomized controlled trials, the incidence of new malignancies was lower in patients receiving sirolimus compared with other immunosuppressive agents. ${ }^{120}$ Because of limited short duration follow-up in the everolimus trials, the magnitude of this effect has not been clearly analyzed as yet (Table 4). In the A2309 study, the incidence of malignancies at 12 months post-transplantation was 3.3\%, 2.9\%, and $5.9 \%$ in patients receiving everolimus $0.75 \mathrm{mg}$ twice daily, everolimus $1.5 \mathrm{mg}$ twice daily, or mycophenolate sodium. ${ }^{64}$

\section{Other mTOR-associated adverse events}

Treatment with mTOR inhibitors has been associated with an increased incidence of peripheral edema, stomatitis and oral ulcers, and pneumonitis. In the A2309 study, the incidence of peripheral edema was higher among patients receiving everolimus compared with mycophenolate sodium $(44.9 \%$ versus $43.5 \%$ versus $39.6 \%$ ). Similarly, stomatitis and oral ulcers were reported as adverse events in 3.3\% versus $5.0 \%$ versus $1.8 \%$ of patients. The overall incidence of lung-related disorders was rare in the A2309 study ( $0.8 \%$ versus $2 \%$ versus $0.4 \%){ }^{64}$ Pneumonitis is an unusual but potentially fatal adverse reaction of this drug class. In a single-center, retrospective study including 205 patients switched from a calcineurin inhibitor to sirolimus $(\mathrm{n}=88)$ or to everolimus $(\mathrm{n}=117)$, six $(2.9 \%)$ developed pneumonitis, one receiving sirolimus and five on everolimus. Pneumonitis was not associated with everolimus or sirolimus blood concentrations. All patients recovered completely after drug withdrawal. ${ }^{121}$

\section{Exposure-effect relationships Exposure-efficacy}

Retrospective ${ }^{60,68}$ and prospective ${ }^{64}$ studies have demonstrated the relationship between everolimus $\mathrm{C}_{\min }$ and risk of biopsyproven acute rejection when everolimus is combined with cyclosporine or tacrolimus. Target everolimus concentrations of 3-8 $\mathrm{ng} / \mathrm{mL}$ were defined, based on these studies, as therapeutic concentrations in combination with reduced calcineurin inhibitor exposure. ${ }^{122}$ The mean dose required to achieve this concentration was $2.6 \mathrm{mg} /$ day when everolimus was combined with cyclosporine ${ }^{64}$ and 3.0-3.5 mg when combined with tacrolimus. ${ }^{67,69}$ However, there is no target concentration defined when everolimus is combined with mycophenolate mofetil/mycophenolate sodium. There is a perception that concentrations should be at the high end or above the target range ( $\geq 8 \mathrm{ng} / \mathrm{mL}$ ) when everolimus is combined with a calcineurin inhibitor. ${ }^{83}$

\section{Exposure-safety}

In studies combining everolimus with cyclosporine, patients randomized to receive the higher-dose level consistently presented an inferior safety profile when compared with the lower-dose level. However, because these studies used either fixed everolimus doses (B201, B251, 2306, 2307, ensuring everolimus levels $>3 \mathrm{ng} / \mathrm{mL}$ ) or only one dose level (B156, CRADUS09, ASSET), only study 2309 was able to address this issue properly. In this study, patients were randomized to receive initial everolimus doses of $0.75 \mathrm{mg}$ twice daily adjusted to obtain an everolimus $\mathrm{C}_{\text {min }}$ of $3-8 \mathrm{ng} / \mathrm{mL}$ or $1.5 \mathrm{mg}$ twice daily adjusted to obtain an everolimus $\mathrm{C}_{\min }$ of $6-12 \mathrm{ng} / \mathrm{mL} .{ }^{122}$

Several class-related adverse events, including dyslipidemia, new-onset diabetes, wound healing complications, and proteinuria appear to be associated with the everolimus $\mathrm{C}_{\min }$. The use of everolimus, regardless of dose or concentration, was associated with an increased risk of oral ulcers and peripheral edema. Everolimus concentrations were not associated with impaired renal function. ${ }^{122,123}$

On the other hand, the significant reduction in cyclosporine concentrations among patients receiving everolimus was associated with significant reductions in cyclosporine-related adverse events. Furthermore, even within the lower range of cyclosporine exposures obtained in patients receiving everolimus, there was an association between cyclosporine concentrations and impaired renal function. ${ }^{122}$

\section{Therapeutic drug monitoring}

Everolimus is a drug with a narrow therapeutic index. The limited and variable bioavailability, intrinsic interindividual pharmacokinetic variability, the number of factors affecting the pharmacokinetics, and the number of drug interactions limits the use of fixed doses of everolimus. The everolimus $\mathrm{C}_{\min }$ is a good surrogate marker of everolimus exposure (AUC), and correlates with pharmacological response and clinical outcomes. Therefore, prospective dose adjustments to obtain and maintain a therapeutic everolimus $\mathrm{C}_{\min }$ have the potential to improve efficacy and reduce toxicity. ${ }^{60}$ Solid organ transplant recipients are maintained on immunosuppressive therapy for long periods. Aggravation of pre-existing comorbidities, new clinical events requiring pharmacological treatment, and noncompliance will likely influence blood drug concentrations and outcomes, underscoring the need for therapeutic drug monitoring. ${ }^{124}$

Several analytic methods are available to quantify everolimus concentrations in blood, including fluorescent polarization immunoassay and liquid chromatography-tandem 
mass spectrometry. Analytical methods to determine everolimus blood concentrations often differ in performance..$^{125,126}$

In 333 predose blood samples from 45 renal transplant patients, everolimus concentrations measured using the fluorescent polarization immunoassay method had acceptable analytical performance, but overestimated everolimus concentrations (mean bias of 24.4\%) compared with high performance liquid chromatography-mass spectrometry. This overestimation is probably due to calibration differences between the methods and cross-reactivity of the fluorescent polarization immunoassay antibody with everolimus metabolites. ${ }^{126}$ In another study including 612 whole blood samples from 28 adult renal transplant recipients, everolimus blood concentrations determined by fluorescent polarization immunoassay showed higher variability, and were $23 \%$ higher than concentrations quantified by liquid chromatography-mass spectrometry. ${ }^{127}$ The clinical relevance of the different performances shown by different assays has not been evaluated.

\section{Risk-benefit analysis and strategy}

The recognition of the efficacy and safety profiles of the everolimus regimens has passed through two distinct phases. First, clinical trials detected that the combination of everolimus and full doses of cyclosporine were associated with inferior graft function, and subsequent studies were designed to reduce this negative impact on renal function in kidney transplant recipients. This was made possible by a substantial decrease $(60 \%)$ in calcineurin inhibitor exposure, ensuring that initial everolimus doses were adjusted to obtain and maintain concentrations above $3 \mathrm{ng} / \mathrm{mL}$, without compromising efficacy in prevention of acute rejection. ${ }^{122}$ Similar observations were made when everolimus was combined with tacrolimus. ${ }^{68}$

Subsequently, more attention was given to adverse events related to drug class and the relationship between these events and blood everolimus concentrations. Everolimus concentrations up to $8 \mathrm{ng} / \mathrm{mL}$ were associated with a lower incidence of proteinuria, wound healing events, dyslipidemia, and diabetes mellitus. ${ }^{64,122,123}$

Therefore, everolimus at an initial dose of $0.75 \mathrm{mg}$ twice daily, adjusted to maintain a blood concentration of $3-8 \mathrm{ng} / \mathrm{mL}$, in combination with a $60 \%$ reduction in the usual doses of cyclosporine, is the strategy that provides the best risk-benefit outcome. ${ }^{64}$ Studies so far have not been able to define the magnitude of the reduction in tacrolimus exposure, but presumably a $40 \%-50 \%$ reduction will maintain the efficacy-safety profile of this drug combination. ${ }^{69}$ Hyperlipidemia appears to be more frequent in patients receiving cyclosporine, whereas diabetes is more prevalent among those receiving tacrolimus (Table 4).

Studies so far have not included a comprehensive proportion of high-risk patients, such as African Americans, sensitized patients, and retransplants. African Americans are known to have a higher risk for acute rejection and graft loss after kidney transplantation. This population usually requires higher doses to benefit from mycophenolate mofetil or sirolimus therapy. ${ }^{128,129}$ African Americans have a 20\% higher clearance of everolimus. ${ }^{39}$ The proportion of African American patients in the everolimus trials was relatively small. Furthermore, in two studies using everolimus in combination with cyclosporine, African American patients were not randomized and received the higher initial dose (1.5 mg twice daily). ${ }^{62}$ In another study, the proportion of African Americans who had trough everolimus concentrations less than $3 \mathrm{ng} / \mathrm{mL}$ was significantly higher ${ }^{68}$ Therefore, more studies are necessary to define the efficacy and therapeutic concentrations of everolimus in this population.

When choosing to use everolimus in combination with a calcineurin inhibitor, one needs to be aware of class-related adverse effects that are not related to blood concentration, such as mouth ulcers and peripheral edema. Wound healing events appear to be related to everolimus concentration, but it remains to be determined whether recovery from ischemiareperfusion injury is or is not associated with everolimus in combination with a calcineurin inhibitor. ${ }^{99}$ Potential advantages of using everolimus also include a lower incidence of viral infections, particularly cytomegalovirus and BK virus, a lower incidence of malignancies, and reduction of calcineurin inhibitor-related adverse events. ${ }^{64}$ Certainly longer-term follow-up is necessary to determine whether the combination of everolimus with reduced doses of calcineurin inhibitors is associated with preservation of renal function.

Conversion from a calcineurin inhibitor to everolimus within the first six months after transplantation may point out the fear of initial use of everolimus regarding initial allograft function and wound healing events. This strategy appears to improve renal function at a cost of a higher incidence of biopsy-proven acute rejection after conversion. ${ }^{83}$ Whether these mild and easily treatable rejection episodes will have any negative impact on graft function in longerterm follow-up is not known. Also, prospective studies are needed to determine the target everolimus concentration in conversion studies when everolimus is combined with mycophenolate mofetil/mycophenolate sodium. This may reduce the risk of rejection after conversion from a calcineurin inhibitor to everolimus. 
Finally, there are no head-to-head studies comparing calcineurin inhibitor reduction and calcineurin inhibitor elimination (conversion to everolimus) strategies. Furthermore, to achieve the proposed benefits of these regimens, long-term tolerability is crucial. Changes in immunosuppressive regimens, regardless of the chosen drug combination, is frequent after transplantation and is mostly related to tolerability and safety issues. ${ }^{5}$

\section{Future perspectives}

There are no prospective studies using everolimus without calcineurin inhibitors in de novo kidney transplant recipients, perhaps because of a higher incidence of acute rejection when sirolimus is used in this setting. ${ }^{101}$ A combination of everolimus with sotrastaurin is under investigation, and may be an alternative calcineurin inhibitor-free strategy for patients at low to moderate risk.

\section{Conclusion}

The bulk of the data indicates that everolimus can be used with reduced exposure to calcineurin inhibitors in de novo kidney transplant candidates at low to moderate risk. Furthermore, of the patient population at low to moderate risk, only a fraction may be converted to everolimus, ie, excluding patients with previous severe rejection, those with already damaged grafts, and those prone to developing recognized adverse reactions, such as dyslipidemia or diabetes associated with everolimus treatment. Because of its immunosuppressive and antineoplastic effects, everolimus may be attractive for the treatment of patients who develop malignancies after transplantation, or as a pre-emptive approach in those with a previous history of malignancy or premalignant lesions. Studies so far do not indicate that everolimus can be used in high-risk patients, such as African Americans, sensitized patients, and retransplants. Limited information is available for these populations. Therapeutic drug monitoring is essential to improve the efficacy/toxicity profile and to improve long-term tolerability.

The potential benefits of everolimus therapy go beyond prevention of acute rejection. Everolimus is associated with a lower incidence of viral infections, may preserve renal function, may be an alternative to manage patients with malignancy, and may be associated with tolerogenic processes, such as induction and maintenance of $\mathrm{T}$ regulatory cells following transplantation. ${ }^{130}$ On the other hand, because of the central role of mTOR in a number of critical intercellular processes in many tissues, it is not surprising that the nonselective inhibition of mTOR by everolimus would be associated with an array of adverse reactions, like any other immunosuppressive drug, including risk of delayed graft function and onset of proteinúria, dyslipidemia, diabetes, myelosuppression, delayed wound healing, infertility, ovarian cysts, and mouth ulcers. ${ }^{131}$

Everolimus may prolong patient and allograft survival by reducing the incidence and severity of certain systemic and graft toxicities associated with the chronic use of calcineurin inhibitors. Nevertheless, to achieve this goal, further investigations aimed to understanding, preventing, and managing everolimus-related adverse reactions are necessary to improve its long-term safety and tolerability.

\section{Disclosure}

HT-S Jr, has received consulting and travel honoraria and grants for research from Novartis, Astellas, Roche, BristolMyers Squibb, Wyeth, Pfizer, and Jansen-Cilag. JOMP has received consulting and travel honoraria and grants for research from Novartis, Astellas, Roche, Bristol-Myers Squibb, Wyeth, Pfizer, and Jansen-Cilag.

\section{References}

1. Meier-Kriesche HU, Schold JD, Srinivas TR, Kaplan B. Lack of improvement in renal allograft survival despite a marked decrease in acute rejection rates over the most recent era. Am J Transplant. 2004; 4(3):378-383.

2. Pascual J, Zamora J, Pirsch JD. A systematic review of kidney transplantation from expanded criteria donors. Am J Kidney Dis. 2008; 52(3):553-586.

3. Kuypers DR. Immunotherapy in elderly transplant recipients: A guide to clinically significant drug interactions. Drugs Aging. 2009;26(9): 715-737.

4. De Bleser L, Matteson M, Dobbels F, Russell C, de Geest S. Interventions to improve medication-adherence after transplantation: A systematic review. Transpl Int. 2009;22(8):780-797.

5. Meier-Kriesche HU, Chu AH, David KM, Chi-Burris K, Steffen BJ. Switching immunosuppression medications after renal transplantation - a common practice. Nephrol Dial Transplant. 2006; 21(8):2256-2262.

6. Marcen R. Immunosuppressive drugs in kidney transplantation: Impact on patient survival, and incidence of cardiovascular disease, malignancy and infection. Drugs. 2009;69(16):2227-2243.

7. Grinyo JM, Cruzado JM. Steroid or calcineurin inhibitor-sparing immunosuppressive protocols. Contrib Nephrol. 2005;146:30-42.

8. Habwe VQ. Posttransplantation quality of life: More than graft function. Am J Kidney Dis. 2006;47(4 Suppl 2):S98-S110.

9. Nickerson P. The impact of immune gene polymorphisms in kidney and liver transplantation. Clin Lab Med. 2008;28(3):455-468, vii.

10. Macphee IA. Use of pharmacogenetics to optimize immunosuppressive therapy. Ther Drug Monit. 2010;32(3):261-264.

11. Christians U, Schmitz V, Schoning W, Bendrick-Peart J, Klawitter J, Haschke M. Toxicodynamic therapeutic drug monitoring of immunosuppressants: Promises, reality, and challenges. Ther Drug Monit. 2008; 30(2):151-158.

12. Wullschleger $\mathrm{S}$, Loewith $\mathrm{R}$, Hall MN. TOR signaling in growth and metabolism. Cell. 2006;124(3):471-484.

13. Neuhaus P, Klupp J, Langrehr JM. mTOR inhibitors: An overview. Liver Transpl. 2001;7(6):473-484. 
14. Nashan B. Review of the proliferation inhibitor everolimus. Expert Opin Investig Drugs. 2002;11(12):1845-1857.

15. Chapman TM, Perry CM. Everolimus. Drugs. 2004;64(8):861-872.

16. Patel JK, Kobashigawa JA. Everolimus: An immunosuppressive agent in transplantation. Expert Opin Pharmacother. 2006;7(10): $1347-1355$.

17. Sanchez-Fructuoso AI. Everolimus: An update on the mechanism of action, pharmacokinetics and recent clinical trials. Expert Opin Drug Metab Toxicol. 2008;4(6):807-819.

18. Dunn C, Croom KF. Everolimus: A review of its use in renal and cardiac transplantation. Drugs. 2006;66(4):547-570.

19. Rostaing L, Kamar N. mTOR inhibitor/proliferation signal inhibitors: Entering or leaving the field? J Nephrol. 2010;23(2):133-142.

20. Gabardi S, Baroletti SA. Everolimus: A proliferation signal inhibitor with clinical applications in organ transplantation, oncology, and cardiology. Pharmacotherapy. 2010;30(10):1044-1056.

21. Kovarik JM, Noe A, Berthier S, et al. Clinical development of an everolimus pediatric formulation: Relative bioavailability, food effect, and steady-state pharmacokinetics. J Clin Pharmacol. 2003;43(2): 141-147.

22. Van Damme-Lombaerts R, Webb NA, Hoyer PF, et al. Single-dose pharmacokinetics and tolerability of everolimus in stable pediatric renal transplant patients. Pediatr Transplant. 2002;6(2):147-152.

23. Hoyer PF, Ettenger R, Kovarik JM, et al. Everolimus in pediatric de novo renal transplant patients. Transplantation. 2003;75(12):2082-2085.

24. Ettenger RB, Grimm EM. Safety and efficacy of TOR inhibitors in pediatric renal transplant recipients. Am J Kidney Dis. 2001; 38(4 Suppl 2):S22-S28.

25. Ettenger R, Hoyer PF, Grimm P, et al. Multicenter trial of everolimus in pediatric renal transplant recipients: Results at three year. Pediatr Transplant. 2008;12(4):456-463.

26. Schuler W, Sedrani R, Cottens S, et al. SDZ RAD, a new rapamycin derivative: Pharmacological properties in vitro and in vivo. Transplantation. 1997;64(1):36-42.

27. Struijk GH, Minnee RC, Koch SD, et al. Maintenance immunosuppressive therapy with everolimus preserves humoral immune responses. Kidney Int. 2010;78(9):934-940.

28. Neumayer HH. Introducing everolimus (Certican) in organ transplantation: An overview of preclinical and early clinical developments. Transplantation. 2005; 79(Suppl 9):S72-S75.

29. Hausen B, Gummert J, Berry GJ, et al. Prevention of acute allograft rejection in nonhuman primate lung transplant recipients: Induction with chimeric anti-interleukin-2 receptor monoclonal antibody improves the tolerability and potentiates the immunosuppressive activity of a regimen using low doses of both microemulsion cyclosporine and 40-O-(2-hydroxyethyl)-rapamycin. Transplantation. 2000;69(4): $488-496$.

30. Eisen HJ, Tuzcu EM, Dorent R, et al. Everolimus for the prevention of allograft rejection and vasculopathy in cardiac-transplant recipients. N Engl J Med. 2003;349(9):847-858.

31. Yuan R, Kay A, Berg WJ, Lebwohl D. Targeting tumorigenesis: Development and use of mTOR inhibitors in cancer therapy. $J$ Hematol Oncol. 2009;2:45.

32. Kirchner GI, Meier-Wiedenbach I, Manns MP. Clinical pharmacokinetics of everolimus. Clin Pharmacokinet. 2004;43(2):83-95.

33. Monchaud C, Marquet P. Pharmacokinetic optimization of immunosuppressive therapy in thoracic transplantation: Part II. Clin Pharmacokinet. 2009;48(8):489-516.

34. Serkova N, Hausen B, Berry GJ, et al. Tissue distribution and clinical monitoring of the novel macrolide immunosuppressant SDZ-RAD and its metabolites in monkey lung transplant recipients: Interaction with cyclosporine. J Pharmacol Exp Ther. 2000;294(1): 323-332.

35. Strom T, Haschke M, Zhang YL, et al. Identification of everolimus metabolite patterns in trough blood samples of kidney transplant patients. Ther Drug Monit. 2007;29(5):592-599.
36. Kovarik JM, Kahan BD, Kaplan B, et al. Longitudinal assessment of everolimus in de novo renal transplant recipients over the first posttransplant year: Pharmacokinetics, exposure-response relationships, and influence on cyclosporine. Clin Pharmacol Ther. 2001;69(1): $48-56$.

37. Budde K, Fritsche L, Waiser J, Glander P, Slowinski T, Neumayer HH. Pharmacokinetics of the immunosuppressant everolimus in maintenance renal transplant patients. Eur J Med Res. 2005;10(4):169-174.

38. Kovarik JM, Kaplan B, Silva HT, et al. Pharmacokinetics of an everolimus-cyclosporine immunosuppressive regimen over the first 6 months after kidney transplantation. Am J Transplant. 2003;3(5): 606-613.

39. Kovarik JM, Hsu CH, McMahon L, Berthier S, Rordorf C. Population pharmacokinetics of everolimus in de novo renal transplant patients: Impact of ethnicity and comedications. Clin Pharmacol Ther. 2001;70(3):247-254.

40. Kovarik JM, Sabia HD, Figueiredo J, et al. Influence of hepatic impairment on everolimus pharmacokinetics: Implications for dose adjustment. Clin Pharmacol Ther. 2001;70(5):425-430.

41. Kahan BD, Wong RL, Carter C, et al. A phase I study of a 4-week course of SDZ-RAD (RAD) quiescent cyclosporine-prednisone-treated renal transplant recipients. Transplantation. 1999;68(8):1100-1106.

42. Kovarik JM, Hartmann S, Figueiredo J, et al. Effect of food on everolimus absorption: Quantification in healthy subjects and a confirmatory screening in patients with renal transplants. Pharmacotherapy. 2002; 22(2):154-159.

43. Kovarik JM, Beyer D, Schmouder RL. Everolimus drug interactions: Application of a classification system for clinical decision making. Biopharm Drug Dispos. 2006;27(9):421-426.

44. Kovarik JM, Kalbag J, Figueiredo J, Rouilly M, Frazier OL, Rordorf C. Differential influence of two cyclosporine formulations on everolimus pharmacokinetics: A clinically relevant pharmacokinetic interaction. J Clin Pharmacol. 2002;42(1):95-99.

45. Kovarik JM, Dantal J, Civati G, et al. Influence of delayed initiation of cyclosporine on everolimus pharmacokinetics in de novo renal transplant patients. Am J Transplant. 2003;3(12):1576-1580.

46. Kovarik JM, Curtis JJ, Hricik DE, Pescovitz MD, Scantlebury V, Vasquez A. Differential pharmacokinetic interaction of tacrolimus and cyclosporine on everolimus. Transplant Proc. 2006;38(10): 3456-3458.

47. Pascual J, del Castillo D, Cabello M, et al. Interaction between everolimus and tacrolimus in renal transplant recipients: A pharmacokinetic controlled trial. Transplantation. 2010;89(8):994-1000.

48. Kovarik JM, Bartlett M, Rordorf C, et al. Sotrastaurin and everolimus pharmacokinetics after single-dose coadministration. Int $J$ Clin Pharmacol Ther. 2010;48(2):103-108.

49. Kovarik JM, Tedesco-Silva H, Lien B, et al. Comparative pharmacokinetics of a sotrastaurin-everolimus versus a cyclosporine-everolimus regimen in de novo kidney transplant recipients: 934. Transplantation. 2010;90:252.

50. Kahan BD, Kaplan B, Lorber MI, Winkler M, Cambon N, Boger RS. RAD in de novo renal transplantation: Comparison of three doses on the incidence and severity of acute rejection. Transplantation. 2001; 71(10): 1400-1406.

51. Vitko S, Margreiter R, Weimar W, et al. Three-year efficacy and safety results from a study of everolimus versus mycophenolate mofetil in de novo renal transplant patients. Am J Transplant. 2005;5(10): 2521-2530.

52. Vitko S, Margreiter R, Weimar W, et al. Everolimus (Certican) 12 -month safety and efficacy versus mycophenolate mofetil in de novo renal transplant recipients. Transplantation. 2004;78(10): 153-140.

53. Lorber MI, Mulgaonkar S, Butt KM, et al. Everolimus versus mycophenolate mofetil in the prevention of rejection in de novo renal transplant recipients: A 3-year randomized, multicenter, phase III study. Transplantation. 2005;80(2):244-252. 
54. Schuurman HJ, Cottens S, Fuchs S, et al. SDZ RAD, a new rapamycin derivative: Synergism with cyclosporine. Transplantation. 1997;64(1): $32-35$.

55. Kuypers DR. Influence of interactions between immunosuppressive drugs on therapeutic drug monitoring. Ann Transplant. 2008;13(3): 11-18.

56. Serkova NJ, Christians U. Biomarkers for toxicodynamic monitoring of immunosuppressants: NMR-based quantitative metabonomics of the blood. Ther Drug Monit. 2005;27(6):733-737.

57. Nashan B, Moore R, Amlot P, Schmidt AG, Abeywickrama K, Soulillou JP. Randomised trial of basiliximab versus placebo for control of acute cellular rejection in renal allograft recipients. CHIB 201 International Study Group. Lancet. 1997;350(9086):1193-1198.

58. Kahan BD, Rajagopalan PR, Hall M. Reduction of the occurrence of acute cellular rejection among renal allograft recipients treated with basiliximab, a chimeric anti-interleukin-2-receptor monoclonal antibody. United States Simulect Renal Study Group. Transplantation. 1999;67(2):276-284.

59. Nashan B, Curtis J, Ponticelli C, Mourad G, Jaffe J, Haas T. Everolimus and reduced-exposure cyclosporine in de novo renal-transplant recipients: A three-year phase II, randomized, multicenter, open-label study. Transplantation. 2004;78(9):1332-1340.

60. Kovarik JM, Tedesco H, Pascual J, et al. Everolimus therapeutic concentration range defined from a prospective trial with reduced-exposure cyclosporine in de novo kidney transplantation. Ther Drug Monit. 2004;26(5):499-505.

61. Keown PA. New concepts in cyclosporine monitoring. Curr Opin Nephrol Hypertens. 2002;11(6):619-626.

62. Vitko S, Tedesco H, Eris J, et al. Everolimus with optimized cyclosporine dosing in renal transplant recipients: 6-month safety and efficacy results of two randomized studies. Am J Transplant. 2004;4(4): 626-635.

63. Tedesco-Silva H Jr, Vitko S, Pascual J, et al. 12-month safety and efficacy of everolimus with reduced exposure cyclosporine in de novo renal transplant recipients. Transpl Int. 2007;20(1):27-36.

64. Tedesco Silva H Jr, Cibrik D, Johnston T, et al. Everolimus plus reduced-exposure cyclosporine versus mycophenolic acid plus standard-exposure cyclosporine in renal-transplant recipients. Am J Transplant. 2010;10(6):1401-1413.

65. Salvadori M, Scolari MP, Bertoni E, et al. Everolimus with very low-exposure cyclosporine a in de novo kidney transplantation: A multicenter, randomized, controlled trial. Transplantation. 2009; 88(10):1194-1202.

66. Dantal J, Berthoux F, Moal MC, et al. Efficacy and safety of de novo or early everolimus with low cyclosporine in deceased-donor kidney transplant recipients at specified risk of delayed graft function: 12-month results of a randomized, multicenter trial. Transpl Int. 2010;23(11):1084-1093.

67. Chan L, Greenstein S, Hardy MA, et al. Multicenter, randomized study of the use of everolimus with tacrolimus after renal transplantation demonstrates its effectiveness. Transplantation. 2008;85(6): 821-826.

68. Chan L, Hartmann E, Cibrik D, Cooper M, Shaw LM. Optimal everolimus concentration is associated with risk reduction for acute rejection in de novo renal transplant recipients. Transplantation. 2010;90(1): 31-37.

69. Hené R, Langer RM, Vitko S, et al. Efficacy benefit with everolimus and very low tacrolimus exposure in de novo renal transplant recipients: 12 month results of the Asset Study: 1549. Transplantation. 2010; 90:109.

70. Nankivell BJ, Borrows RJ, Fung CL, O'Connell PJ, Allen RD, Chapman JR. The natural history of chronic allograft nephropathy. N Engl J Med. 2003;349(24):2326-2333.

71. Flechner SM, Kobashigawa J, Klintmalm G. Calcineurin inhibitorsparing regimens in solid organ transplantation: Focus on improving renal function and nephrotoxicity. Clin Transplant. 2008;22(1):1-15.
72. Gutierrez-Dalmau A, Campistol JM. Immunosuppressive therapy and malignancy in organ transplant recipients: A systematic review. Drugs. 2007;67(8):1167-1198.

73. Pohanka E. Conversion to everolimus in maintenance patients current clinical strategies. Nephrol Dial Transplant. 2006;21 Suppl 3: iii24-iii29.

74. Ruiz JC, Sanchez-Fructuoso A, Rodrigo E, et al. Conversion to everolimus in kidney transplant recipients: A safe and simple procedure. Transplant Proc. 2006;38(8):2424-2426.

75. Sanchez Fructuoso A, Ruiz San Millan JC, Calvo N, et al. Evaluation of the efficacy and safety of the conversion from a calcineurin inhibitor to an everolimus-based therapy in maintenance renal transplant patients. Transplant Proc. 2007;39(7):2148-2150.

76. Holdaas H, Bentdal O, Pfeffer P, Mjornstedt L, Solbu D, Midtvedt K Early, abrupt conversion of de novo renal transplant patients from cyclosporine to everolimus: Results of a pilot study. Clin Transplant. 2008;22(3):366-371.

77. Giron F, Baez Y, Nino-Murcia A, Rodriguez J, Salcedo S. Conversion therapy to everolimus in renal transplant recipients: Results after one year. Transplant Proc. 2008;40(3):711-713.

78. Ayala M, Morales J, Fierro A, Herzog C, Calabran L, Buckel E. Metabolic changes following conversion from an anticalcineurinbased therapy to an everolimus-based one: A single-center experience. Transplant Proc. 2008;40(9):3265-3269.

79. Inza A, Balda S, Alvarez E, Zarraga S, Gainza FJ, Lampreabe I. Conversion to everolimus in kidney transplant recipients with decreased renal function. Transplant Proc. 2009;41(6):2134-2136.

80. Cataneo-Davila A, Zuniga-Varga J, Correa-Rotter R, Alberu J. Renal function outcomes in kidney transplant recipients after conversion to everolimus-based immunosuppression regimen with CNI reduction or elimination. Transplant Proc. 2009;41(10):4138-4146.

81. Ruiz JC, Sanchez A, Rengel M, et al. Use of the new proliferation signal inhibitor everolimus in renal transplant patients in Spain: Preliminary results of the EVERODATA registry. Transplant Proc. 2007;39(7):2157-2159.

82. Bemelman FJ, de Maar EF, Press RR, et al. Minimization of maintenance immunosuppression early after renal transplantation: An interim analysis. Transplantation. 2009;88(3):421-428.

83. Becker T, Arns W, Budde K, et al. Improved renal function of an everolimus/enteric-coated mycophenolate sodium regimen after calcineurin inhibitor withdrawal in de novo renal transplant patients: 2 years follow-up of the Zeus Trial: 1757. Transplantation. 2010; 90:109.

84. Ruiz JC, Fructuoso SA, Hernández D, et al. An appraisal on the convenience of early everolimus introduction and calcineurin inhibitor withdrawal in kidney recipients: the Eric Study: 2165. Transplantation. 2010;90:223.

85. Pascual J, Fernandez AM, Marcen R, Ortuno J. Conversion to everolimus in a patient with arterial hypertension and recurrent cutaneous neoplasia - a case report. Nephrol Dial Transplant. 2006;21 Suppl 3: iii38-iii41.

86. de Fijter JW. Use of proliferation signal inhibitors in non-melanoma skin cancer following renal transplantation. Nephrol Dial Transplant. 2007;22 Suppl 1:i23-i26.

87. Campistol JM, Schena FP. Kaposi's sarcoma in renal transplant recipients - the impact of proliferation signal inhibitors. Nephrol Dial Transplant. 2007;22 Suppl 1:i17-i22.

88. Pascual J. Post-transplant lymphoproliferative disorder - the potential of proliferation signal inhibitors. Nephrol Dial Transplant. 2007; 22 Suppl 1:i27-i35.

89. Chiurchiu C, Carreno CA, Schiavelli R, et al. Results of the conversion to everolimus in renal transplant recipients with posttransplantation malignancies. Transplant Proc. 2010;42(1):277-279.

90. Gutierrez-Dalmau A, Campistol JM. The role of proliferation signal inhibitors in post-transplant malignancies. Nephrol Dial Transplant. 2007;22 Suppl 1:i11-i16. 
91. Campistol JM, Albanell J, Arns W, et al. Use of proliferation signal inhibitors in the management of post-transplant malignancies - clinical guidance. Nephrol Dial Transplant. 2007;22 Suppl 1: i36-i41.

92. Ram R, Swarnalatha G, Neela P, Dakshinamurty KV. Sirolimus-induced aphthous ulcers which disappeared with conversion to everolimus. Saudi J Kidney Dis Transpl. 2008;19(5):819-820.

93. Rehm B, Keller F, Mayer J, Stracke S. Resolution of sirolimusinduced pneumonitis after conversion to everolimus. Transplant Proc. 2006;38(3):711-713.

94. Kamar N, Jaafar A, Esposito L, et al. Conversion from sirolimus to everolimus in maintenance renal transplant recipients within a calcineurin inhibitor-free regimen: Results of a 6-month pilot study. Clin Nephrol. 2008;70(2):118-125.

95. Lui SL, Chan KW, Tsang R, Yung S, Lai KN, Chan TM. Effect of rapamycin on renal ischemia-reperfusion injury in mice. Transpl Int. 2006;19(10):834-839.

96. Lieberthal W, Fuhro R, Andry CC, et al. Rapamycin impairs recovery from acute renal failure: Role of cell-cycle arrest and apoptosis of tubular cells. Am J Physiol Renal Physiol. 2001;281(4): F693-F706.

97. Durrbach A, Rostaing L, Tricot L, et al. Prospective comparison of the use of sirolimus and cyclosporine in recipients of a kidney from an expanded criteria donor. Transplantation. 2008;85(3): 486-490.

98. Stallone G, Di Paolo S, Schena A, et al. Addition of sirolimus to cyclosporine delays the recovery from delayed graft function but does not affect 1-year graft function. J Am Soc Nephrol. 2004;15(1): 228-233.

99. Albano L, Berthoux F, Moal MC, et al. Incidence of delayed graft function and wound healing complications after deceased-donor kidney transplantation is not affected by de novo everolimus. Transplantation. 2009;88(1):69-76.

100. Dean PG, Lund WJ, Larson TS, et al. Wound-healing complications after kidney transplantation: A prospective, randomized comparison of sirolimus and tacrolimus. Transplantation. 2004;77(10): 1555-1561.

101. Ekberg H, Tedesco-Silva H, Demirbas A, et al. Reduced exposure to calcineurin inhibitors in renal transplantation. $N$ Engl J Med. 2007;357(25):2562-2575.

102. Margreiter R, Vitko Š, Whelchel J, et al. Post-operative tissue regeneration in renal transplantation: Comparable outcome with everolimus or MMF: 538. Transplantation. 2008;86(2S):188.

103. Letavernier E, Legendre C. mToR inhibitors-induced proteinuria: Mechanisms, significance, and management. Transplant Rev (Orlando). 2008;22(2):125-130.

104. Biancone L, Bussolati B, Mazzucco G, et al. Loss of nephrin expression in glomeruli of kidney-transplanted patients under mTOR inhibitor therapy. Am J Transplant. 2010;10(10): 2270-2278.

105. Badiou S, Cristol JP, Mourad G. Dyslipidemia following kidney transplantation: Diagnosis and treatment. Curr Diab Rep. 2009;9(4): 305-311.

106. Kasiske BL, de Mattos A, Flechner SM, et al. Mammalian target of rapamycin inhibitor dyslipidemia in kidney transplant recipients. Am J Transplant. 2008;8(7):1384-1392.

107. Balla A, Chobanian M. New-onset diabetes after transplantation: A review of recent literature. Curr Opin Organ Transplant. 2009;14(4):375-379.

108. Johnston O, Rose CL, Webster AC, Gill JS. Sirolimus is associated with new-onset diabetes in kidney transplant recipients. J Am Soc Nephrol. 2008;19(7):1411-1418.

109. Preiksaitis JK, Brennan DC, Fishman J, Allen U. Canadian society of transplantation consensus workshop on cytomegalovirus management in solid organ transplantation final report. Am J Transplant. 2005;5(2):218-227.
110. Webster AC, Lee VW, Chapman JR, Craig JC. Target of rapamycin inhibitors (sirolimus and everolimus) for primary immunosuppression of kidney transplant recipients: A systematic review and meta-analysis of randomized trials. Transplantation. 2006;81(9): 1234-1248.

111. Fortun J, Martin-Davila P, Pascual J, et al. Immunosuppressive therapy and infection after kidney transplantation. Transpl Infect Dis. 2010;12(5):397-405.

112. Kim YS, Tedesco-Silva H, Johnston T, et al. Lower incidence of cytomegalovirus and BK virus with everolimus versus mycophenolate in de novo renal transplant patients: Results from a multicenter, prospective study: 1615. Transplantation. 2010;90:256.

113. Ramos E, Drachenberg CB, Wali R, Hirsch HH. The decade of polyomavirus BK-associated nephropathy: State of affairs. Transplantation. 2009;87(5):621-630.

114. Fortin MC, Raymond MA, Madore F, et al. Increased risk of thrombotic microangiopathy in patients receiving a cyclosporine-sirolimus combination. Am J Transplant. 2004;4(6):946-952.

115. Reynolds JC, Agodoa LY, Yuan CM, Abbott KC. Thrombotic microangiopathy after renal transplantation in the United States. Am J Kidney Dis. 2003;42(5):1058-1068.

116. Sartelet H, Toupance O, Lorenzato M, et al. Sirolimus-induced thrombotic microangiopathy is associated with decreased expression of vascular endothelial growth factor in kidneys. Am J Transplant. 2005;5(10):2441-2447.

117. Ponticelli C. De novo thrombotic microangiopathy. An underrated complication of renal transplantation. Clin Nephrol. 2007;67(6): 335-340.

118. Robson M, Cote I, Abbs I, Koffman G, Goldsmith D. Thrombotic microangiopathy with sirolimus-based immunosuppression: Potentiation of calcineurin-inhibitor-induced endothelial damage? Am J Transplant. 2003;3(3):324-327.

119. Stevens B, Flechner S, Wei LJ, et al. Similar risk of renal graft loss due to thrombosis for everolimus versus MPA-based regimens: 1875. Transplantation. 2010;90:439.

120. Campistol JM, Eris J, Oberbauer R, et al. Sirolimus therapy after early cyclosporine withdrawal reduces the risk for cancer in adult renal transplantation. J Am Soc Nephrol. 2006;17(2):581-589.

121. Rodriguez-Moreno A, Ridao N, Garcia-Ledesma P, et al. Sirolimus and everolimus induced pneumonitis in adult renal allograft recipients: Experience in a center. Transplant Proc. 2009;41(6): 2163-2165.

122. Chan L, Cibrik D, Johnston T, et al. Correlation of everolimus exposure with efficacy and safety outcomes: Results from a multicenter study in renal transplantation using reduced CsA exposure: 2027. Transplantation. 2010;90:111.

123. Vathsala A, Zibari G, Kim YS, et al. Dose related incidences of wound healing events in renal transplant recipients treated with everolimus and cyclosporine: 2060. Transplantation. 2010;90:615.

124. Mabasa VH, Ensom MH. The role of therapeutic monitoring of everolimus in solid organ transplantation. Ther Drug Monit. 2005;27(5): 666-676.

125. Korecka M, Shaw LM. Review of the newest HPLC methods with mass spectrometry detection for determination of immunosuppressive drugs in clinical practice. Ann Transplant. 2009;14(2):61-72.

126. Salm P, Warnholtz C, Boyd J, Arabshahi L, Marbach P, Taylor PJ. Evaluation of a fluorescent polarization immunoassay for whole blood everolimus determination using samples from renal transplant recipients. Clin Biochem. 2006;39(7):732-738.

127. Moes DJ, Press RR, de Fijter JW, Guchelaar HJ, den Hartigh J. Liquid chromatography-tandem mass spectrometry outperforms fluorescence polarization immunoassay in monitoring everolimus therapy in renal transplantation. Ther Drug Monit. 2010;32(4):413-419.

128. Podder H, Podbielski J, Hussein I, Katz S, van Buren C, Kahan BD. Sirolimus improves the two-year outcome of renal allografts in African-American patients. Transpl Int. 2001;14(3):135-142. 
129. Neylan JF. Immunosuppressive therapy in high-risk transplant patients: Dose-dependent efficacy of mycophenolate mofetil in African-American renal allograft recipients. US Renal Transplant Mycophenolate Mofetil Study Group. Transplantation. 1997;64(9): 1277-1282.

130. Geissler EK, Schlitt HJ. The potential benefits of rapamycin on renal function, tolerance, fibrosis, and malignancy following transplantation. Kidney Int. 2010;78(11):1075-1079.
131. Cravedi P, Ruggenenti P, Remuzzi G. Sirolimus for calcineurin inhibitors in organ transplantation: Contra. Kidney Int. 2010;78(11): 1068-1074.

\section{Publish your work in this journal}

Transplant Research and Risk Management is an international, peerreviewed open access journal focusing on all aspects of transplantation and risk management to achieve optimal outcomes in the recipien improving survival and quality of life. The journal welcomes submitted papers covering original research, basic science, clinical studies, reviews
\& evaluations, guidelines, expert opinion and commentary, case reports and extended reports. The manuscript management system is completely online and includes a very quick and fair peer-review system, which is all easy to use. Visit http://www.dovepress.com/testimonials. php to read real quotes from published authors.

Submit your manuscript here: http://www.dovepress.com/transplant-research-and-risk-management-journal 